\title{
Water-soluble rhenium clusters with triazoles: the effect of chemical structure on cellular internalization and the DNA
} binding of the complexes

\author{
Dmitry I. Konovalov, ${ }^{[a]}$ Anton A. Ivanov, ${ }^{[a]}$ Tatiana S. Frolova,,${ }^{[b, c]}$ Ilia V. Eltsov, ${ }^{[b]}$ Yakov M. Gayfulin, ${ }^{[a]}$ \\ Louis Plunkett, ${ }^{[d]}$ Masoomeh Bazzar, ${ }^{[d]}$ Ali M. Adawi, ${ }^{[d]}$ Jean-Sebastien G. Bouillard, ${ }^{[d]}$ \\ Sergey I. Baiborodin, ${ }^{[\mathrm{c}]}$ Olga I. Sinitsyna, ${ }^{[\mathrm{b}, \mathrm{c}]}$ Natalia V. Kuratieva, ${ }^{[\mathrm{a}]}$ Vadim V. Yanshole,,${ }^{[a, b, e]}$ \\ Olga A. Efremova, ${ }^{*[d]}$ Michael A. Shestopalov ${ }^{*[a]}$
}

[a] D.I. Konovalov, Dr. A.A. Ivanov, Dr. Y.M. Gayfulin, Dr. N.V. Kuratieva, Dr. V.V. Yanshole, Dr. M.A. Shestopalov Nikolaev Institute of Inorganic Chemistry SB RAS

3 acad. Lavrentiev ave., 630090 Novosibirsk (Russia)

E-mail: shtopy@niic.nsc.ru (M.A. Shestopalov)

[b] Dr. T.S. Frolova, Dr. I.V. Eltsov, Dr. O.I. Sinitsyna, Dr. V.V. Yanshole Novosibirsk State University

2 Pirogova st., 630090 Novosibirsk (Russia)

[c] Dr. T.S. Frolova, Dr. S.I. Baiborodin, Dr. O.I. Sinitsyna

Federal Research Center Institute of Cytology and Genetics SB RAS

10 acad. Lavrentiev ave., 630090 Novosibirsk (Russia)

[d] L. Plunkett, M. Bazzar, Dr. A.M. Adawi, Dr. J.-S.G. Bouillard, Dr. O.A. Efremova

School of Mathematics and Physical Sciences

G.W. Gray Centre for Advanced Materials University of Hull

Cottingham Road, HU6 7RX, Hull (UK)

E-mail : olgaa.efremova@gmail.com (O.A. Efremova)

[e] Dr. V.V. Yanshole

International Tomography Centre SB RAS

3a Institutskaya st., 630090 Novosibirsk (Russia)

Supporting information for this article is given via a link at the end of the document.

\begin{abstract}
Here we explore the effect of the nature of organic ligands in rhenium cluster complexes $\left[\mathrm{Re}_{6} \mathrm{Q}_{8} \mathrm{~L}_{6}\right]^{4-}$ (where $\mathrm{Q}=\mathrm{S}$ or $\mathrm{Se}$, and $\mathrm{L}=$ benzotriazole, 1,2,3-triazole or 1,2,4-triazole) on the biological properties of the complexes, in particular on the cellular toxicity, cellular internalization and localization. Specifically, the paper describes the synthesis and detailed characterization of the structure, luminescence and electrochemical properties of the four new $\mathrm{Re}_{6}$ clusters with 1,2,3- and 1,2,4-triazoles. Biological assays of these complexes are also discussed in addition to those with benzotriazole using cervical cancer (HeLa) and immortalized human fibroblasts (CRL-4025) as model cell lines. Our study demonstrates that the presence of hydrophobic and m-bonding rich units such as the benzene ring in benzotriazole significantly enhances cellular internalization of rhenium clusters. These ligands facilitate binding of the clusters to DNA, which results in increased cytotoxicity of the complexes.
\end{abstract}

\section{Introduction}

Octahedral rhenium cluster complexes with the general formula $\left[\left\{\operatorname{Re}_{6} \mathrm{Q}_{8}\right\} \mathrm{L}_{6}\right]^{\mathrm{n}}(\mathrm{Q}=\mathrm{S}, \mathrm{Se}, \mathrm{Te})$ have gathered significant interest due to their good phosphorescence properties in red/near infrared region of the spectrum, ${ }^{[1]}$ high $\mathrm{X}$-ray attenuation, ${ }^{[2]}$ and their ability to generate singlet oxygen. ${ }^{[3]}$ Hence these cluster have a high potential for applications associated with photodynamic inactivation of malignant cells and bacteria. Moreover, octahedral rhenium clusters have significantly higher chemical, electrochemical and thermal stability than their molybdenum and tungsten analogues.
Despite having such superb properties, only a handful of complexes were tested in biomedical (bioimaging and biolabeling, ${ }^{[4]}$ as X-ray contrast agents ${ }^{[2]}$ or photodynamic therapy $(\mathrm{PDT})^{[3 \mathrm{~b}]}$ ) and materials-based applications (e.g. organic lightemitting diodes (OLEDs) $)^{[5]}$ and liquid crystals ${ }^{[6]}$ ). In the context of the biological applications, there is an obstacle associated with the limited choice of water-soluble octahedral rhenium clusters. Indeed, up until recently the known water-soluble clusters were those with the inorganic, highly hydrophilic ligands, $\mathrm{CN}^{-}$and $\mathrm{OH}^{-}{ }^{[7]}$ Although these complexes demonstrated high biomedical potential, the scarcity of such hydrophilic ligands cannot offer much freedom to fine-tune biologically active properties, in particular cellular internalization profiles and cellular localization of the complexes to suit particular biomedical applications. For example, optical bioimaging and PDT agents must in some way participate in intracellular processes or interact with components participating in the processes. Therefore, such diagnostics and therapies require agents with good cellular internalization and preferably targeted localization within the cells (e.g. in the perinuclear region in case of PDT), while $X$-ray contrast agents should display the least possible interaction with body constituents and processes to offer greater patient tolerance. ${ }^{[8]}$ To expand our understanding of the biological potential of octahedral rhenium complexes and to be able to tune their biological properties, our group has developed new methods to synthesize octahedral rhenium clusters that bear organic ligands. ${ }^{[4,9]}$ 9amely, octahedral rhenium cluster complexes with organic ligands can be obtained by the direct reaction of fully inorganic cluster precursors in molten organic pro-ligand at relatively high temperature $\left(150-200{ }^{\circ} \mathrm{C}\right)$ or using a solvothermal process. For example, using these approaches the first water- 
This is the peer reviewed version of the following article: D. I. Konovalov, A. A. Ivanov, T. S. Frolova, I. V. Eltsov, Y. M. Gayfulin, L. Plunkett, M. Bazzar, A. M. Adawi, J.-S. G. Bouillard, S. I. Baiborodin, O. I. Sinitsyna, N. V. Kuratieva, V. V. Yanshole, O. A. Efremova, M. A.

Shestopalov, Chem. Eur. J. 2020, 26, 13904., which has been published in final form at https://doi.org/10.1002/chem.202001680. This article may be used for non-commercial purposes in accordance with Wiley Terms and Conditions for self-archiving.

soluble rhenium cluster complexes with organic phosphine-based ligands $\mathrm{Na}_{4}\left[\left\{\mathrm{Re}_{6} \mathrm{Q}_{8}\right\}\left(\mathrm{PPh}_{2} \mathrm{CH}_{2} \mathrm{CH}_{2} \mathrm{COO}\right)_{6}\right] \quad\left(\mathrm{Q}=\mathrm{S}\right.$, Se), ${ }^{\left[{ }^{\mathrm{b}}\right]}$ $\mathrm{Na}_{2}\{\mathrm{H}\}_{14}\left[\left\{\mathrm{Re}_{6} \mathrm{Q}_{8}\right\}\left(\mathrm{P}\left(\mathrm{CH}_{2} \mathrm{CH}_{2} \mathrm{COO}\right)_{3}\right)_{6}\right] \quad(\mathrm{Q}=\mathrm{S} \text {, Se })^{[9 \mathrm{~d}]}$ and $\mathrm{Na}_{2}\{\mathrm{H}\}_{8}\left[\left\{\mathrm{Re}_{6} \mathrm{Se} 8\right\}\left(\mathrm{P}\left(\mathrm{CH}_{2} \mathrm{CH}_{2} \mathrm{CONH}_{2}\right)\left(\mathrm{CH}_{2} \mathrm{CH}_{2} \mathrm{COO}\right)_{2}\right)_{6}\right] \quad$ were obtained. ${ }^{[9 c, 10]}$ The cellular internalization of these complexes was studied on larynx carcinoma (Hep-2) and cervical cancer (HeLa) cell lines. The studies indeed demonstrated that compounds with a dual-nature (hydrophilic and hydrophobic) ligand $\mathrm{PPh}_{2} \mathrm{CH}_{2} \mathrm{CH}_{2} \mathrm{COOH}$ are readily taken in by the cells with localization in cytoplasm, while highly negatively charged complexes with hydrophilic ligands $\left(\mathrm{P}\left(\mathrm{CH}_{2} \mathrm{CH}_{2} \mathrm{COO}\right)_{3}\right)^{3-}$ or $\left(\mathrm{P}\left(\mathrm{CH}_{2} \mathrm{CH}_{2} \mathrm{CONH}_{2}\right)\left(\mathrm{CH}_{2} \mathrm{CH}_{2} \mathrm{COO}\right)_{2}\right)^{2-}$ were not taken in by the cells. On the other hand, cytotoxicity and acute in vivo toxicity patterns of the complexes was influenced not only by the ability of the complex to internalize into the cells but also by the number of ions a complex produces in a solution. Indeed, it was demonstrated by in vitro and in vivo studies that the toxicity of $\mathrm{Na}_{2}\{\mathrm{H}\}_{8}\left[\left\{\mathrm{Re}_{6} \mathrm{Se}_{8}\right\}\left(\mathrm{P}\left(\mathrm{C}_{2} \mathrm{H}_{4} \mathrm{CONH}_{2}\right)\left(\mathrm{C}_{2} \mathrm{H}_{4} \mathrm{COO}\right)_{2}\right)_{6}\right] \quad$ aqueous solutions was considerably lower than $\mathrm{Na}_{2}\{\mathrm{H}\}_{14}\left[\left\{\mathrm{Re}_{6} \mathrm{Q}_{8}\right\}\left(\mathrm{P}\left(\mathrm{CH}_{2} \mathrm{CH}_{2} \mathrm{COO}\right)_{3}\right)_{6}\right]$ with a fully hydrolyzed ligand in the form of $\mathrm{P}\left(\mathrm{C}_{2} \mathrm{H}_{4} \mathrm{COOH}\right)_{3}$ due to higher osmolality of the latter. ${ }^{[9 d]}$

Reactions of $\mathrm{K}_{4}\left[\operatorname{Re}_{6} \mathrm{Q}_{8}(\mathrm{OH})_{6}\right](\mathrm{Q}=\mathrm{S}$, Se) in molten benzotriazole (btrzH) pro-ligand also lead to water-soluble compounds $\left[\left\{\operatorname{Re}_{6} Q_{8}\right\}(b t r z)_{6}\right]^{4-}(Q=S \text {, Se })^{[4 b]}$ Studies on Hep-2 cells demonstrated that the complexes internalized well into the cells with predominant localization in perinuclear area. These complexes were shown to be at least 10 -fold more cytotoxic than the equivalent phosphine analogues.

In this work, we were keen to explore the effect of the benzene ring within benzotriazole on their cellular toxicity, internalization and localization of the rhenium cluster complexes in more detail. To do that we have synthesized and characterized new rhenium cluster complexes $\left[\left\{\operatorname{Re}_{6} Q_{8}\right\}\left(L_{6}\right)_{6}\right]^{4-}$, where $Q=S$ and $L=1,2,3$ triazolate (1,2,3-trz) (1), Q = Se and $L=1,2,3$-triazolate (2), $Q=$ $S$ and $L=1,2,4$-triazolate (1,2,4-trz) (3), or $Q=S e$ and $L=1,2,4$ triazolate (4) to compare their biological properties, such as cytotoxicity and genotoxicity, internalization and localization within the HeLa and CRL-4025 (immortalized human fibroblasts) to those of $\left[\left\{\operatorname{Re}_{6} \mathrm{Q}_{8}\right\}(\mathrm{btrz})_{6}\right]^{4-}(\mathrm{Q}=\mathrm{S}(\mathbf{5})$, Se (6)) (Table 1).

Table 1. Abbreviations of compounds used in the manuscript.

\begin{tabular}{cc}
\hline Compound & Abbreviation \\
\hline$\left[\left\{\operatorname{Re}_{6} \mathrm{~S}_{8}\right\}\left(1,2,3-\mathrm{trz}_{6}\right]^{4-}\right.$ & $\mathbf{1}$ \\
{$\left[\left\{\mathrm{Re}_{6} \mathrm{Se}_{8}\right\}(1,2,3-\mathrm{trz})_{6}\right]^{4-}$} & $\mathbf{2}$ \\
{$\left[\left\{\mathrm{Re}_{6} \mathrm{~S}_{8}\right\}(1,2,4-\mathrm{trz})_{6}\right]^{4-}$} & $\mathbf{3}$ \\
{$\left[\left\{\mathrm{Re}_{6} \mathrm{Se}_{8}\right\}(1,2,4-\mathrm{trz})_{6}\right]^{4-}$} & $\mathbf{4}$ \\
{$\left[\left\{\operatorname{Re}_{6} \mathrm{~S}_{8}\right\}(\mathrm{btrz})_{6}\right]^{4-}$} & $\mathbf{5}$ \\
{$\left[\left\{\mathrm{Re}_{6} \mathrm{Se}_{8}\right\}(\mathrm{btrz})_{6}\right]^{4-}$} & $\mathbf{6}$
\end{tabular}

\section{Results and Discussion}

Synthesis and characterization of cluster complexes
The synthesis and characterization of rhenium complexes with benzotriazole, $\quad \mathrm{K}_{4}\left[\left\{\mathrm{Re}_{6} \mathrm{~S}_{8}\right\}(\mathrm{btrz})_{6}\right] \cdot 3.5 \mathrm{EtOH} \cdot 4 \mathrm{H}_{2} \mathrm{O} \quad\left(\mathrm{K}_{4}-\right.$ 5.3.5EtOH$\left.\cdot 4 \mathrm{H}_{2} \mathrm{O}\right)$ and $\mathrm{K}_{2.75} \mathrm{H}_{1.25}\left[\left\{\mathrm{Re}_{6} \mathrm{Se}_{8}\right\}(\mathrm{btrz})_{6}\right] \cdot 3 \mathrm{EtOH} \cdot 7 \mathrm{H}_{2} \mathrm{O}$ $\left(\mathrm{K}_{4}-6 \cdot 3 \mathrm{EtOH} \cdot 7 \mathrm{H}_{2} \mathrm{O}\right)$ has been reported before. ${ }^{[4 \mathrm{~b}]}$ In order to eliminate the toxic effects of $\mathrm{K}^{+}$ions and to increase the solubility of the compounds, sodium salts of the cluster complexes were used for biological studies. Sodium salts $\mathrm{Na}_{4}\left[\left\{\mathrm{Re}_{6} \mathrm{Q}_{8}\right\}(\mathrm{btrz})_{6}\right]\left(\mathrm{Na}_{4}-\right.$ 5 and $\left.\mathrm{Na}_{4}-6\right)$ were obtained in a similar fashion, i.e. the reaction of sodium salt of hydroxo clusters $\left[\left\{\operatorname{Re}_{6} Q_{8}\right\}(O H)_{6}\right]^{4-}(Q=S$ or $\mathrm{Se})$ using corresponding molten pro-ligands as reaction media. Indeed, our previous systematic studies demonstrated that such reactions, where a reactive pro-ligand is a protic agent, lead to a complete substitution of all six apical ligands. ${ }^{[4 b, 9 b, 11]}$ The reaction melts were dissolved in ethanol and crystallized as neat $\mathrm{Na}_{4}-5$ and $\mathrm{Na}_{4}-6$. Elemental analyses, NMR (Fig. S1-S6), EDX and FTIR unambiguously confirmed the similarity of the sodium cluster complex to the potassium analogue.

Although the overall approach for the synthesis of octahedral clusters bearing 1,2,3-triazole and 1,2,4-triazole is generally the same, the isolation of the neat complexes was more complicated. Unlike benzotriazole complexes, precipitation of anions 1-4 from the ethanol solutions of the melts resulted in solvates $\mathrm{Cat}_{4}\left[\left\{\mathrm{Re}_{6} \mathrm{Q}_{8}\right\} \mathrm{L}_{6}\right] \cdot x(\mathrm{LH}) \cdot y\left(\mathrm{H}_{2} \mathrm{O}\right) \cdot z(\mathrm{EtOH})$, i.e. co-precipitated with molecules of the triazoles. The isolation of the neat complexes required a few extra steps: the conversion of the salt into the neutral water-insoluble $\left[\left\{\operatorname{Re}_{6} \mathrm{Q}_{8}\right\}(\mathrm{LH})_{4} \mathrm{~L}_{2}\right]$ with the help of $1 \mathrm{M} \mathrm{HCl}$, a few washing cycles with water followed by the conversion of the neutral complex back into the salt and finally recrystallization from DMSO by precipitation of the neat product with ethyl acetate. The product, as assessed by CHNS analysis, sometimes contained 12 molecules of DMSO per formula unit, which could be isolated by re-precipitation from ethanol by $\mathrm{CH}_{2} \mathrm{Cl}_{2}$.

Only one chemical form was found in the solution in the case of 1,2,3-triazole compounds in which the ligand is coordinated by the nitrogen atom in position 1 when examining both one-dimensional and two-dimensional spectra (Fig. 1, S7-S12).

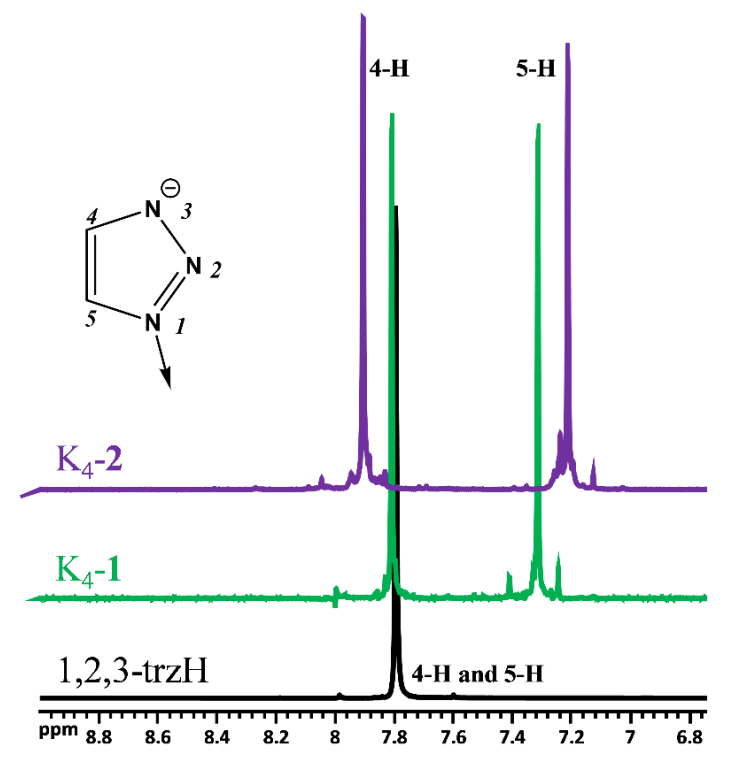

Figure 1. Fragment of ${ }^{1} \mathrm{H}$ NMR spectra of $\mathrm{K}_{4}-1$ and $\mathrm{K}_{4}-2$ in comparison with 1,2,3-triazole in DMSO-d 6 . 
This is the peer reviewed version of the following article: D. I. Konovalov, A. A. Ivanov, T. S. Frolova, I. V. Eltsov, Y. M. Gayfulin, L. Plunkett, M. Bazzar, A. M. Adawi, J.-S. G. Bouillard, S. I. Baiborodin, O. I. Sinitsyna, N. V. Kuratieva, V. V. Yanshole, O. A. Efremova, M. A. Shestopalov, Chem. Eur. J. 2020, 26, 13904., which has been published in final form at https://doi.org/10.1002/chem.202001680. This article may be used for non-commercial purposes in accordance with Wiley Terms and Conditions for self-archiving.

However, it is difficult to assign signals of the first and second nitrogen atoms. The assignment given in Figure 1 is based on the assumption that the influence of the cluster nucleus has a deshielding effect and affects the first coordinated nitrogen atom to a greater extent, displacing the corresponding NMR peak to a weaker field. Upon coordination the position of the signal from hydrogen atom $5-\mathrm{H}$ (i.e. the closest to the coordinating atom of nitrogen) is shifted upfield from $7.795 \mathrm{ppm}$ to 7.311 or $7.210 \mathrm{ppm}$ for $Q=S$ or Se, respectively (Fig. 1).

In contrast, the spectra of $\mathrm{K}_{4}-\mathbf{3}$ and $\mathrm{K}_{4} \mathbf{- 4}$ are far more complicated (Fig. 2, S13-S20). Various forms of complexes were found in the solution, which differ in the coordination of the ligand. The composition of the complexes can be described by the general formula $\mathrm{K}_{4}\left[\left\{\operatorname{Re}_{6} \mathrm{Q}_{8}\right\}(1,2,4-\mathrm{trz})^{\mathrm{type}}{ }_{\mathrm{n}}\left(1,2,4-\right.\right.$ trz $\left.^{\mathrm{typell}}{ }_{6-\mathrm{n}}\right]$, where type ${ }^{\mathrm{l}}$ is the ligand coordinated by the nitrogen atom in the first position of the heterocycle, type ${ }^{\prime \prime}-$ is in the fourth position. According to this it can be calculated that, in general, up to 10 isomers are possible. The assignment of nitrogen atoms was carried out on the basis of changes in chemical shifts in comparison with free 1,2,4triazole. ${ }^{[12]}$ According to ${ }^{[13]}$, non-coordinating nitrogen atoms in the 1,2,4-triazole fragment and practically do not change their position in comparison to the chemical shifts in the free ligand. For

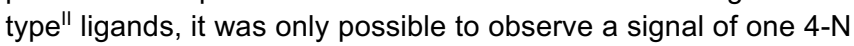
atom. Most likely, this is due to the process of tautomeric exchange, which results in 1-N and 2- $\mathrm{N}$ atoms being equivalent to each other and thus not appearing in the two-dimensional spectrum.

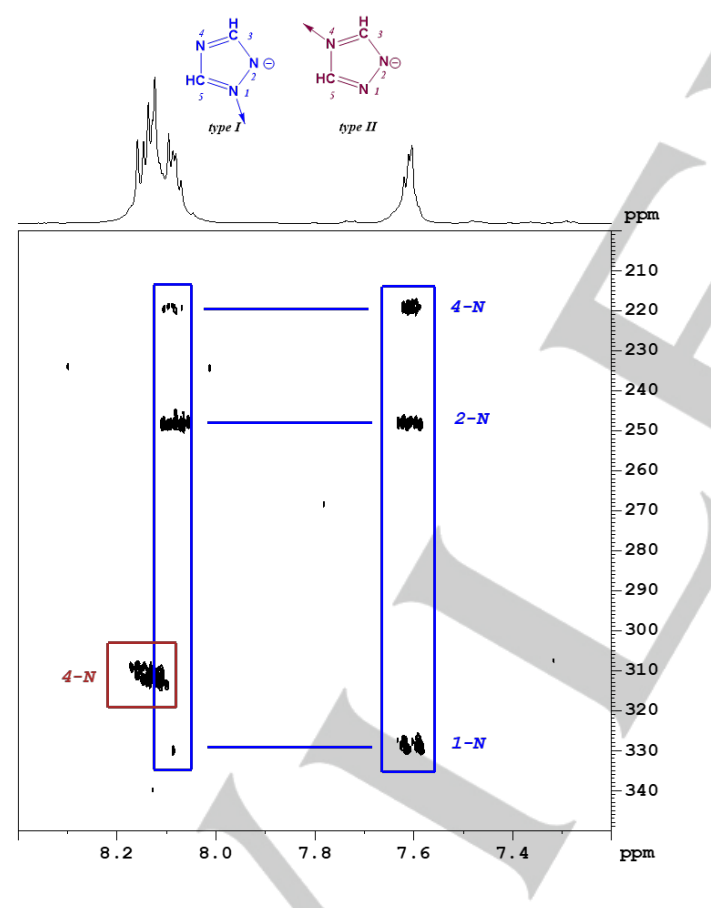

Figure 2. ${ }^{1} \mathrm{H},{ }^{15} \mathrm{~N}-\mathrm{NMR}$ HMBC spectrum of $\mathrm{K}_{4}-1$ in DMSO-d 6 .

The assignment of signals in the ${ }^{1} \mathrm{H}$ and ${ }^{13} \mathrm{C}$ spectra is based on two-dimensional C, $\mathrm{H}$ and N, H correlations (Fig. S17-S20). One can say that in both cases following the integrated signal intensities, the proportion of coordinated ligands of type "is slightly dominant and equal to $55 \%$ and $58 \%$ for $\mathrm{Q}=\mathrm{S}$ and $\mathrm{Se}$, respectively. The dominancy of type" ligand in the NMR signifies that nitrogen atom in position 4 is a stronger nucleophile, despite the fact that type' ligand should statistically appear twice as frequently due to equivalency of nitrogen atoms in the position 1 and 2. On the other hand, the fact of presence of complexes with type' ligands in the NMR suggests that coordination reaction is irreversible, while the formation of the complexes is controlled by kinetics.

The results obtained from mass-spectroscopy are also in the agreement with the suggested molecular formula: namely the spectra of all four compounds feature signals that contain forms with six triazole ligands as well as daughter species with the number of apical ligands below 6 (Fig. S21-S24).

Crystallographic studies

For the 1,2,3-triazole compounds, we managed to attain crystals and to determine three single crystal structures. Namely $\mathrm{K}_{4}-$ 1.6(1,2,3-trzH) $4 \mathrm{H}_{2} \mathrm{O}, \mathrm{K}_{4}-2 \cdot 6(1,2,3-\mathrm{trz} \mathrm{H})$, obtained directly from the reaction mixture before purification and $\mathrm{Na}_{4}-1 \cdot 4 \mathrm{EtOH} \cdot 10 \mathrm{H}_{2} \mathrm{O}$ obtained after the purification. For ions $\mathbf{3}$ and $\mathbf{4}$, no crystal compounds were obtained, which is likely to be due to the presence of a high variety of structural and geometric isomers.

Compound $\mathrm{K}_{4}-1 \cdot 6(1,2,3$-trzH $) \cdot 4 \mathrm{H}_{2} \mathrm{O}$ contains the anions $\left[\left\{\operatorname{Re}_{6} \mathrm{~S}_{8}\right\}(1,2,3-\mathrm{trz})_{6}\right]^{4-}$ predicted by NMR (Fig. 3a). Terminal triazole ligands in trans positions form chains via solvate water molecules and potassium cations, where $\mathrm{N}$...K contacts are 2.79 $\AA$ and O...K contacts are 2.64-2.81 $\AA$ (Fig. S25a). These potassium cations are also involved in the interaction with four solvate 1,2,3-triazole molecules through N...K (2.80 $\AA$ ) and CH...K (C...K $3.04 \AA)$ contacts. Such chains are connected by $\mathrm{N}-$ $\mathrm{H}$... N hydrogen bonds between two another 1,2,3-triazole ligands and solvate 1,2,3-triazole molecules in chains ( $\mathrm{N}$...N distance is $2.82 \AA$ ) (Fig. S25b). The remaining two terminal ligands are also involved in $\mathrm{N}-\mathrm{H}$...N hydrogen bonds with the two remaining solvate triazole molecules ( $\mathrm{N}$...N distance is $2.78 \AA$ ). In contrast to $\mathrm{K}_{4}-1 \cdot 6(1,2,3-\operatorname{trz} \mathrm{H}) \cdot 4 \mathrm{H}_{2} \mathrm{O}$, cluster anions in $\mathrm{K}_{4}-2 \cdot 6(1,2,3-$ trzH) are connected with each other via solvate molecules of 1,2,3triazole and potassium cations (Fig. S26). These interactions can be described as a distorted $\mathrm{K}_{8}$ cube connected with six apical 1,2,3-triazole ligands from six different cluster anions through N...K contacts $(2.88 \AA)$ and six solvate 1,2,3-triazoles through N...K (3.03-3.12 $\AA)$ and C-H...K (C...K 2.97-3.12 $\AA)$ contacts.
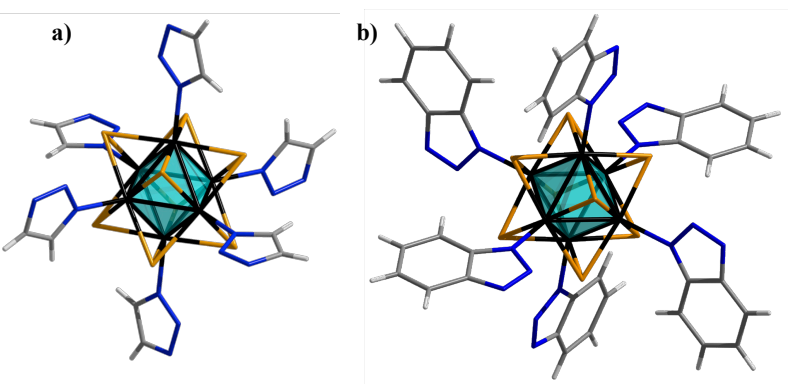

Figure 3. (a) The structure of $\left[\left\{\operatorname{Re}_{6} Q_{8}\right\}(1,2,3-\operatorname{trz})_{6}\right]^{4-}$ (b) The structure of $\left[\left\{\operatorname{Re}_{6} \mathrm{Q}_{8}\right\}(\mathrm{btrz})_{6}\right]^{4-}$ is given for comparison.

In the structure of $\mathrm{Na}_{4}-1 \cdot 4 \mathrm{EtOH} \cdot 10 \mathrm{H}_{2} \mathrm{O}$, the cluster anions 1 are connected by complex chain-like cations $[(\mathrm{EtOH}) \mathrm{Na}(\mu-$ $\left.\left.\mathrm{H}_{2} \mathrm{O}\right)_{3} \mathrm{Na}(\mathrm{EtOH})\left(\mu-\mathrm{H}_{2} \mathrm{O}\right)_{2} \mathrm{Na}(\mathrm{EtOH})\left(\mu-\mathrm{H}_{2} \mathrm{O}\right)_{3} \mathrm{Na}(\mathrm{EtOH})\right]^{4+}$

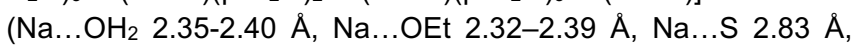
$\mathrm{Na}$...N $2.48 \AA$ ) (Fig. S27). The chains are also connected via hydrogen bonds between $\mathrm{H}_{2} \mathrm{O}$ molecules of the complex cation and the organic ligands where the $\mathrm{N}$...O distances are equal to 
This is the peer reviewed version of the following article: D. I. Konovalov, A. A. Ivanov, T. S. Frolova, I. V. Eltsov, Y. M. Gayfulin, L. Plunkett, M. Bazzar, A. M. Adawi, J.-S. G. Bouillard, S. I. Baiborodin, O. I. Sinitsyna, N. V. Kuratieva, V. V. Yanshole, O. A. Efremova, M. A. Shestopalov, Chem. Eur. J. 2020, 26, 13904., which has been published in final form at https://doi.org/10.1002/chem.202001680. This article may be used for non-commercial purposes in accordance with Wiley Terms and Conditions for self-archiving.

$2.92 \AA$. The voids between the chains are filled with 2 molecules of $\mathrm{H}_{2} \mathrm{O}$ per formula unit.

Optical and electrochemical properties

The luminescent properties of compounds $\mathrm{K}_{4}-\mathbf{1 - 4}$ were characterized in the solid state and in deaerated aqueous solutions, since the luminescence of octahedral clusters quenches well with molecular oxygen. The emission spectra and the luminescence decay profiles are given in Fig S28-S35, while the photophysical characteristics: emission maximum wavelengths $\left(\lambda_{\mathrm{em}}\right)$, emission lifetimes $\left(\mathrm{Tem}_{\mathrm{em}}\right)$ and quantum yields $\left(\Phi_{\text {em }}\right)$ in Table 2.

Table 2. Spectroscopic and photophysical parameters of compounds $K_{4}-n$ ( $n=$ $1,2,3,4)$ in comparison with literature data for $\mathrm{K}_{4}-\mathbf{5}$ and $\mathrm{K}_{4}-\mathbf{6}$.

\begin{tabular}{|c|c|c|c|c|c|c|}
\hline & $\mathrm{K}_{4}-1$ & $\mathrm{~K}_{4}-2$ & $\mathrm{~K}_{4}-3$ & $\mathrm{~K}_{4}-4$ & $\mathrm{~K}_{4}-5^{[\mathrm{a}]}$ & $\mathrm{K}_{4}-6^{[\mathrm{a}]}$ \\
\hline \multicolumn{7}{|c|}{ Solid state } \\
\hline$\lambda_{\max }, \mathrm{nm}$ & 645 & 667 & 650 & 659 & 700 & 700 \\
\hline$\Phi$ & 0.15 & 0.06 & 0.20 & 0.23 & 0.075 & 0.083 \\
\hline $\mathrm{T}, \mu \mathrm{s}$ & 7.4 & 9.1 & 8.2 & 9.8 & $7.6,2.9$ & $7.7,1.8$ \\
\hline \multicolumn{7}{|c|}{ Deaerated $\mathrm{H}_{2} \mathrm{O}$ solution, $\mathrm{pH}=7$} \\
\hline$\lambda_{\max }, \mathrm{nm}$ & 650 & 660 & 645 & 655 & 705 & 700 \\
\hline$\Phi$ & $<0.01$ & $<0.01$ & $<0.01$ & 0.03 & 0.014 & 0.018 \\
\hline $\mathrm{T}, \mu \mathrm{s}$ & 6.6 & 8.5 & 5.8 & 3.8 & 2.6 & 3.4 \\
\hline
\end{tabular}

Deaerated $\mathrm{H}_{2} \mathrm{O}$ solution, $\mathrm{pH}=9$

$\begin{array}{ccccccc}\lambda_{\max }, \mathrm{nm} & 650 & 660 & 646 & 657 & - & - \\ \Phi & <0.01 & 0.01 & <0.01 & 0.03 & - & - \\ \text { T, HS } & 5.9 & 8.4 & 7.2 & 3.2 & - & -\end{array}$

Deaerated $\mathrm{D}_{2} \mathrm{O}$ solution, $\mathrm{pH}=7$

\begin{tabular}{ccccccc}
$\lambda_{\max } \mathrm{nm}$ & 650 & 660 & 650 & 659 & - & - \\
$\Phi$ & 0.07 & 0.04 & 0.02 & 0.05 & - & - \\
$\mathrm{T}, \mu \mathrm{S}$ & 22.6 & 11.8 & 21.9 & 9.0 & - & - \\
\hline
\end{tabular}

[a] from [4b], the data in $\mathrm{H}_{2} \mathrm{O}$ soliton was at $\mathrm{pH}>6$

Overall, the luminescent properties of the triazole complexes are similar to those reported for the benzotriazole analogues and other related compounds. ${ }^{[4 b, 11]}$ One can note from the data that the emission profile of the compounds is mostly dependent on the nature of the core rather than ligand. This is because the emission in the octahedral clusters originates from the triplet excited state, which is cluster core centered with only little input from apical ligands orbitals. ${ }^{[14]}$ This weak contribution of the ligands in the orbital was also confirmed by measurements of luminescence at different $\mathrm{pH}$ values (at $\mathrm{pH}=7$ and $\mathrm{pH}=9$ ): although the ligands, being weak bases, do participate in the acid-base equilibria, no difference in fluorescence was found. Unfortunately, solution experiments at acidic $\mathrm{pH}$ were impossible due to poor solubility of the compounds in acidic medium. Notably the luminescence quantum yield measured in deaerated $\mathrm{H}_{2} \mathrm{O}$ solutions are noticeably smaller than that in the solid state, although the lifetimes are comparable. We believe that the reduction of $\Phi_{\mathrm{em}}$ in aqueous medium is due to luminescence quenching via non- radiative energy transfer to $\mathrm{H}_{2} \mathrm{O}$ vibrations in water molecules. ${ }^{[3 \mathrm{~b}]}$ Indeed, experiments undertaken in deaerated $\mathrm{D}_{2} \mathrm{O}$ lead to a noticeable increase of both the photoluminescence quantum yield values and the lifetimes values.

The oxidation of compounds $\mathrm{K}_{4}-1-6$ was recorded in DMSO against an $\mathrm{Ag} / \mathrm{AgCl}$ electrode. Figure 4 demonstrates the cyclic voltammogram of the compounds, while Table $\mathrm{S} 1$ summarizes the oxidation and reduction potentials. All complexes undergo a reversible one-electron oxidation, to give 23ē cluster species. In a similar manner to the luminescence properties, the potentials are only slightly dependent on the nature of the apical ligands and mostly are determined by the nature of the cluster core: selenium cluster complexes are more prone to oxidation than the sulfur analogues, for which the potentials are $\sim 0.2 \mathrm{~V}$ higher. This behavior is rather typical for octahedral $24 \bar{e}$ metal clusters and it signifies the decrease of the energy of HOMO orbital with the decrease of electronegativity of the inner ligand, ${ }^{[1 \mathrm{~b}, 15]}$ since this orbital is also mostly constituted from orbitals of the cluster core. It should be, however, noted that in the case of anions $\mathbf{2}$ and $\mathbf{4}$ the anodic peak is significantly broader and less defined. We presume this is due to the variety of isomers (observed by NMR spectroscopy) present in the solution, each with a slightly different oxidation potential. Apart from a one-electron oxidation, the cluster complexes also undergo a quasi-reversible reduction at $-0.75 \mathrm{~V}$, which is associated with the organic ligand-centered reduction. Such a reduction was described earlier for rhenium complexes with pyridine-based ligands or molybdenum complexes with 3,5-dinitrobenzoate. ${ }^{[16]}$
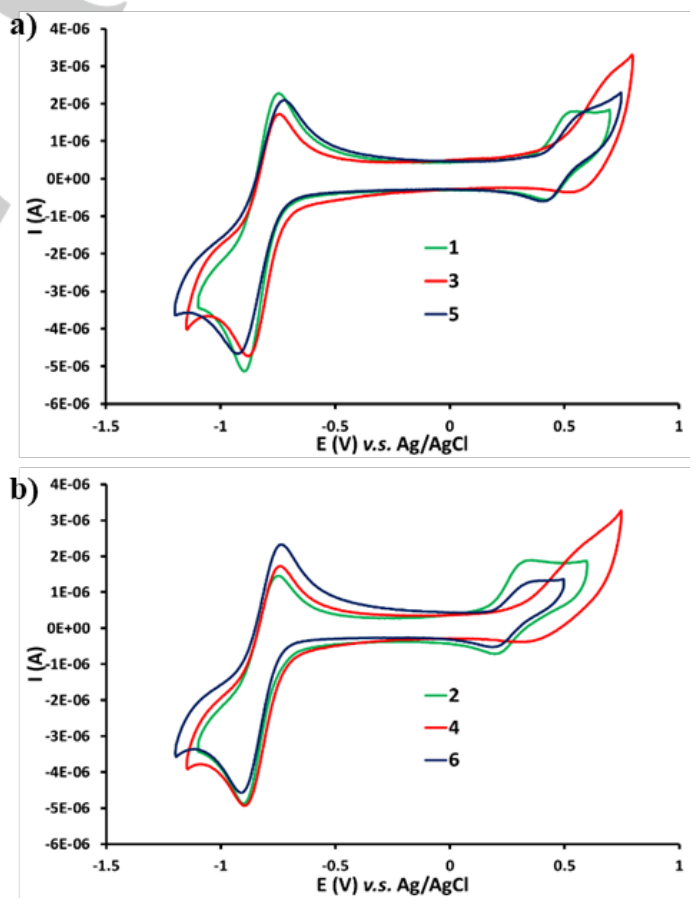

Figure 4. Cyclic voltammetry of the $\left[\left\{\operatorname{Re}_{6} Q_{8}\right\} L_{6}\right]^{4-}(Q=S(a)$, Se (b)) anions $(0.5$ $\mathrm{mM}$ ) in $0.1 \mathrm{M} \mathrm{Bu}_{4} \mathrm{NClO}_{4}$ DMSO solution.

\section{Biological studies}

The biological properties of the cluster anions 1-4 and the benzotriazole analogues 5-6 were studied using sodium salts rather the potassium to reduce the possible negative effect of the potassium ions, which will be paramount for any in vivo studies in 
This is the peer reviewed version of the following article: D. I. Konovalov, A. A. Ivanov, T. S. Frolova, I. V. Eltsov, Y. M. Gayfulin, L. Plunkett, M. Bazzar, A. M. Adawi, J.-S. G. Bouillard, S. I. Baiborodin, O. I. Sinitsyna, N. V. Kuratieva, V. V. Yanshole, O. A. Efremova, M. A Shestopalov, Chem. Eur. J. 2020, 26, 13904., which has been published in final form at https://doi.org/10.1002/chem.202001680. This article may be used for non-commercial purposes in accordance with Wiley Terms and Conditions for self-archiving.

future. The toxicity profile was studied on cervical cancer cells (HeLa) and on the immortalized human fibroblasts (CRL-4025) cell line using the MTT assay and the results are presented in Figure 5, while values of $\mathrm{IC}_{50}$ are summarized in Table 3. According to our data, all six compounds had moderate toxicity to either of the cell lines with both of benzotriazole complexes being the most toxic from the lot.
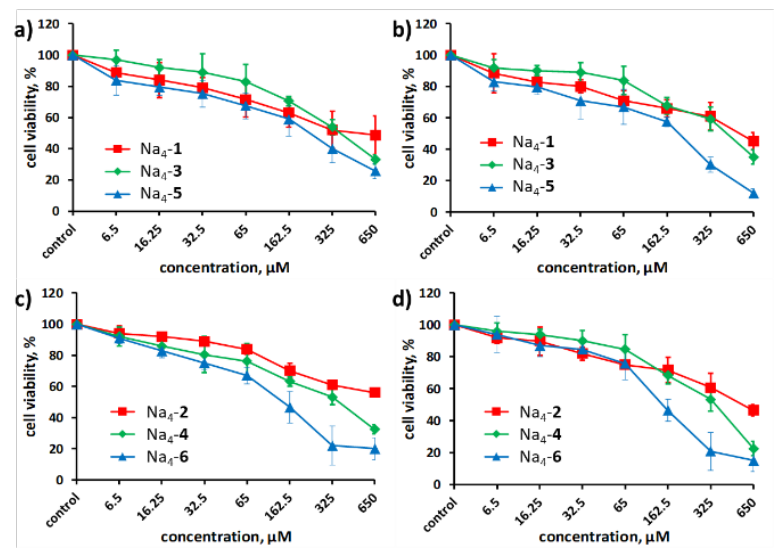

Figure 5. Cellular toxicity of Na4-n detected by the MTT assay on HeLa (a,c) and CRL-4025 (b,d) cells.

Table 3. The $\mathrm{IC}_{50}$ of $\mathrm{Na}_{4}-\mathrm{n}$ on the HeLa and CRL-4025 determined by the MTT assay

\begin{tabular}{|c|c|c|}
\hline \multirow[t]{2}{*}{ Compound } & \multicolumn{2}{|c|}{$\mathrm{IC}_{50 \pm} \pm \mathrm{SEM}, \mu \mathrm{M}$} \\
\hline & HeLa & CRL-4025 \\
\hline $\mathrm{Na}_{4}-1$ & $370 \pm 30$ & $550 \pm 30$ \\
\hline $\mathrm{Na}_{4}-2$ & $>650$ & $540 \pm 70$ \\
\hline $\mathrm{Na}_{4}-3$ & $370 \pm 30$ & $430 \pm 40$ \\
\hline $\mathrm{Na}_{4}-4$ & $380 \pm 10$ & $350 \pm 20$ \\
\hline $\mathrm{Na}_{4}-5$ & $230 \pm 20(123.7 \pm 0.8)^{[a]}$ & $190 \pm 10$ \\
\hline $\mathrm{Na}_{4}-6$ & $140 \pm 10(122.6 \pm 0.2)^{[a]}$ & $160 \pm 10$ \\
\hline
\end{tabular}

[a] from ${ }^{[4 b]}$ for potassium salts on Hep-2 cells

The uptake of the cluster complexes by the cells was monitored by confocal microscopy and by flow cytometry. The distributions of the cells treated by the clusters according to their Flow scattering (FSC) vs the intensity of red luminescence $(710 \mathrm{~nm})$ are presented in Fig. S36. One can see that although the gated population sets in the case of the cells treated by Na4-1-6 were not identical with the control population set, the sets overlapped significantly and thus could not be easily distinguished. Therefore, the mean luminescence intensity per cell was calculated for the sake of comparison (Fig. 6). The data demonstrate that, indeed, both cell lines were on average statistically more luminescent than the control. However, the strongest difference in luminescence for the cells treated by the clusters was found in the case of $\mathrm{Na}_{4}-6$, which suggests that this complex was taken by the cells more efficiently. The confocal microscopy was performed for investigation of intracellular distribution of clusters. For the experiment both cell lines were incubated with $0.65 \mathrm{mM}$ solutions of the clusters for $24 \mathrm{~h}$ and analyzed by confocal microscope under excitation at $405 \mathrm{~nm}$ and emission detection at 650-700 nm and the results are presented at the Figure 7 and S37. According to confocal images all of the cluster complexes, in particular for $\mathrm{Na}_{4}-6$, entered the cancer cell line better than the fibroblasts. Moreover, as one can see both $\mathrm{Na}_{4}-\mathbf{5}$ and $\mathrm{Na}_{4}-\mathbf{6}$ also penetrated efficiently into the nucleus, which may explain the increased cytotoxicity of these complexes. In contrast, with the exception to Na4-6, the red luminescence from fibroblasts was significantly less pronounced. It should also be noted that the character of emission from the cells treated by the benzotriazole complexes is visually different from that of triazole complexes: it is rather evenly distributed within the nucleus and perinuclear region, while emission from triazole complexes appears in punctate manner in the cytoplasm, which may suggest precipitation/aggregation of clusters onto or within the cells.

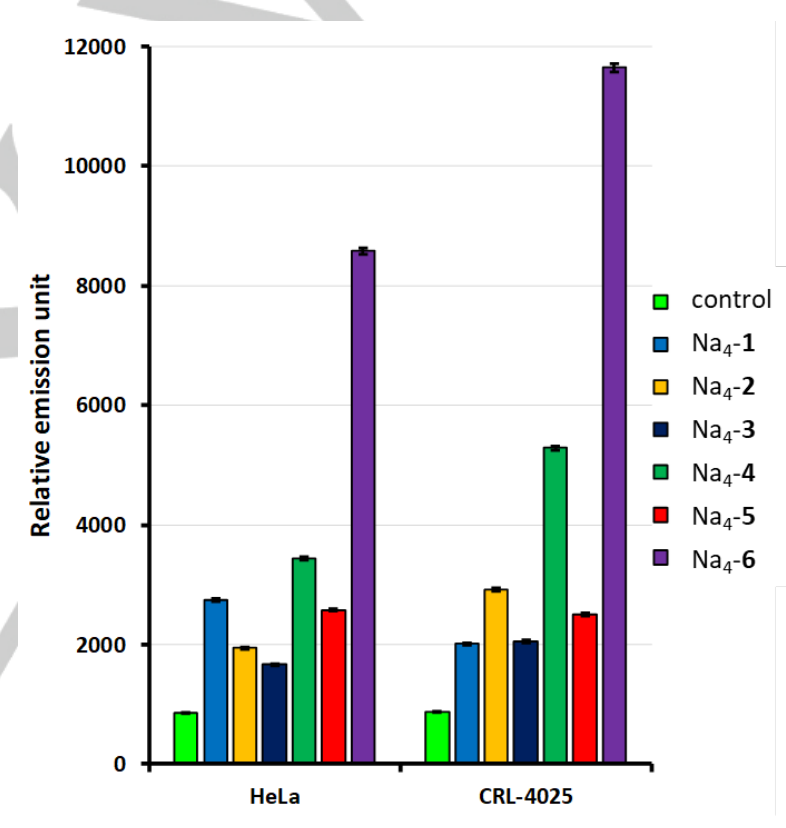

Figure 6. The uptake of the cluster complexes by HeLa and CRL-4025 cell lines, expressed as a relative emission unit (REU $\pm S E M)$.

Having determined that cluster anions $\mathbf{5}$ and $\mathbf{6}$ do have preferential localization in nucleus we were interested to understand whether they also able to bind to DNA. We first attempted to evaluate the interaction between the clusters and DNA by electrophoresis. Clusters at concentration of $0.04 \mu \mathrm{M}$ were incubated with plasmid DNA at $37^{\circ}$ for $24 \mathrm{~h}$ followed by electrophoresis. The results are presented at Fig. S38. As one can see there is no clear change between pure DNA and DNA with cluster, which means even if there are interaction between the complexes and DNA, they are week. 
This is the peer reviewed version of the following article: D. I. Konovalov, A. A. Ivanov, T. S. Frolova, I. V. Eltsov, Y. M. Gayfulin, L. Plunkett, M. Bazzar, A. M. Adawi, J.-S. G. Bouillard, S. I. Baiborodin, O. I. Sinitsyna, N. V. Kuratieva, V. V. Yanshole, O. A. Efremova, M. A.

Shestopalov, Chem. Eur. J. 2020, 26, 13904., which has been published in final form at https://doi.org/10.1002/chem.202001680. This article may be used for non-commercial purposes in accordance with Wiley Terms and Conditions for self-archiving.

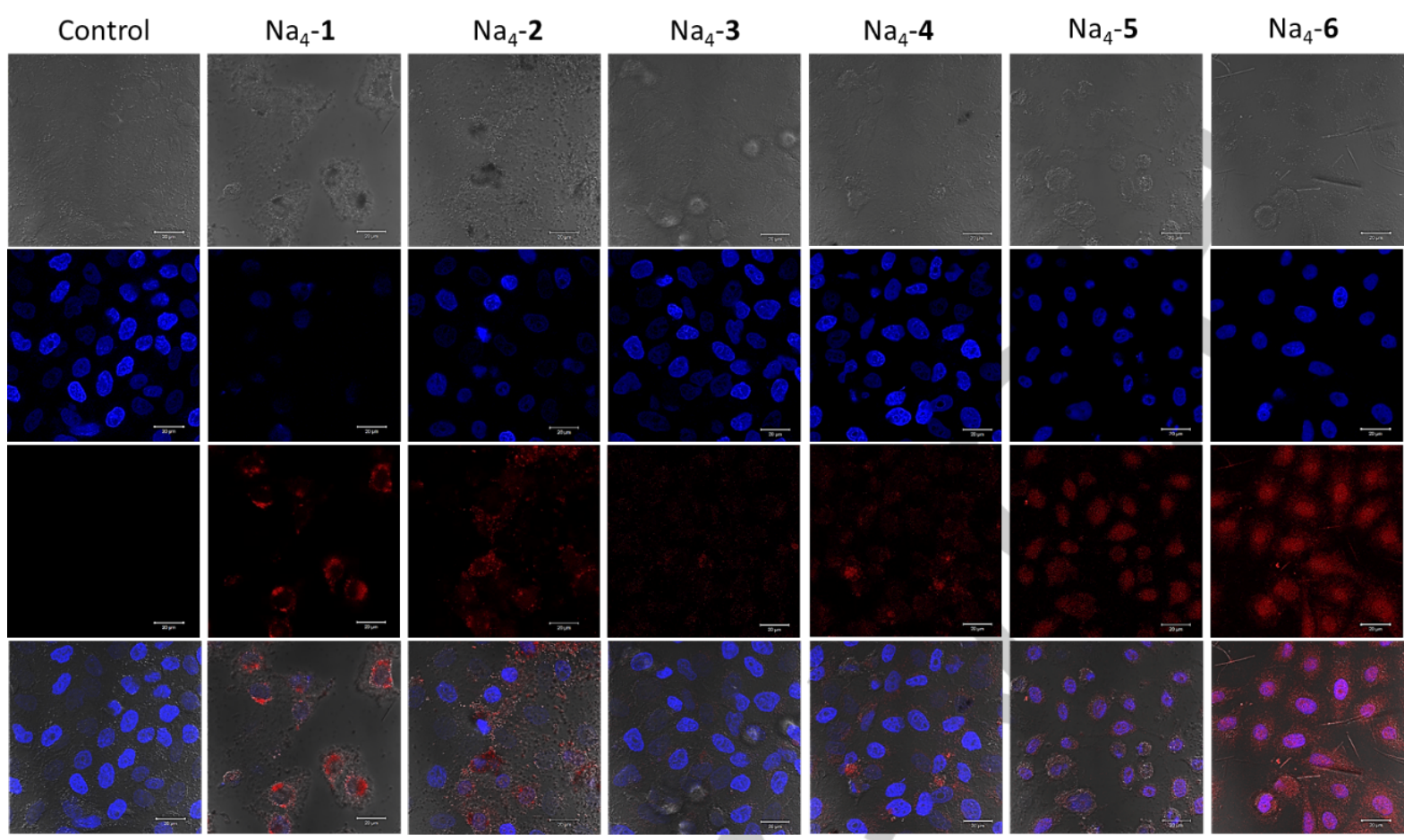

Figure 7. Intracellular distribution of clusters in HeLa cell line. Cell nuclei are colored by DAPI (blue), the luminescence of clusters is red.

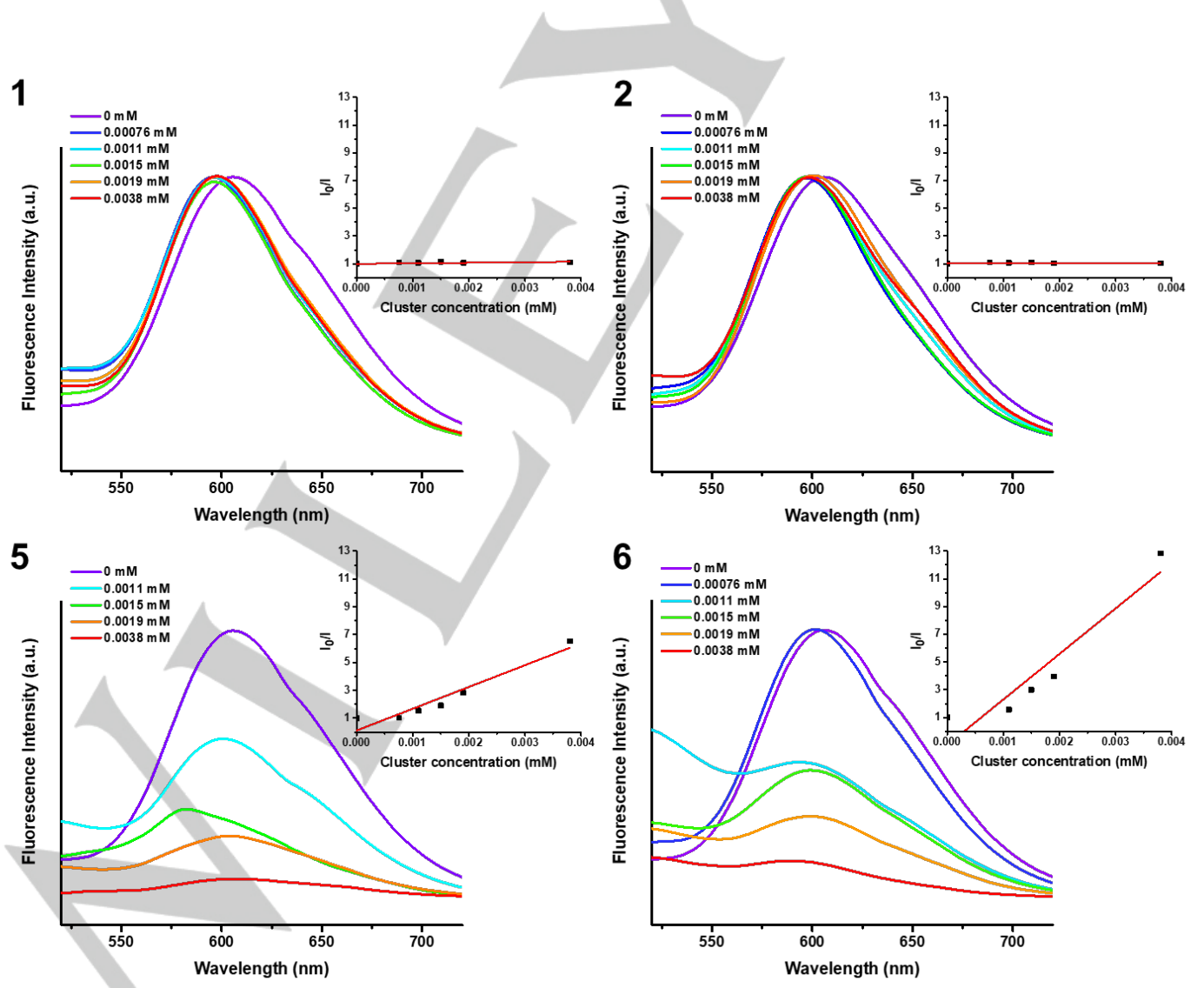

Figure 8. Effect of the rhenium cluster anions 1, 2, 5 and $\mathbf{6}$ on the fluorescence emission of the EB-ctDNA complex. 
This is the peer reviewed version of the following article: D. I. Konovalov, A. A. Ivanov, T. S. Frolova, I. V. Eltsov, Y. M. Gayfulin, L. Plunkett, M. Bazzar, A. M. Adawi, J.-S. G. Bouillard, S. I. Baiborodin, O. I. Sinitsyna, N. V. Kuratieva, V. V. Yanshole, O. A. Efremova, M. A.

Shestopalov, Chem. Eur. J. 2020, 26, 13904., which has been published in final form at https://doi.org/10.1002/chem.202001680. This article may be used for non-commercial purposes in accordance with Wiley Terms and Conditions for self-archiving.

We than attempted fluorescence-based measurements as they should have higher sensitivity. It is known that Ethidium Bromide (EB) emits intense fluorescence in the presence of ctDNA, due to its strong intercalation between the adjacent $c t D N A$ base pairs. ${ }^{[17]}$ The quenching of the fluorescence of EB/ctDNA mixture in the presence of moieties capable to bind to ctDNA can be used to determine the extent of binding between the second molecule and ctDNA. The competitive binding experiments were carried out in TRIS buffer by keeping [DNA]:[EB] $=10: 1$ and varying the concentrations of $\mathrm{Na}_{4}-1, \mathrm{Na}_{4}-2, \mathrm{~K}_{4}-5$ and $\mathrm{K}_{4}-6$ between 0 and $3.8 \times 10^{-2} \mathrm{mM}$, where the upper limit of the cluster concentration in the experiment was established by undertaking a separate set of experiments in the absence of ctDNA (see below). The fluorescence spectra of EB were measured between 520 and 720 $\mathrm{nm}$ using an excitation wavelength of $405 \mathrm{~nm}$ and the emission range was set. The spectra were analyzed according to the classical Stern-Volmer Equation:

$$
\frac{I_{0}}{I}=1+K_{S V} C
$$

where $I_{0}$ and $I$ are the integrated fluorescence intensities in the absence and presence of the quencher, respectively, $\mathrm{K}_{\mathrm{sv}}$ is the linear Stern-Volmer quenching constant, $C$ is the concentration of the quencher. The emission spectra and the Stern-Volmer plots are presented in Figure 8. As one can see, the 1,2,3-triazole containing clusters ( $\mathbf{1}$ and $\mathbf{2}$ ) exhibited insignificant binding affinity to ctDNA. This contrasted substantially by the btrz-containing clusters (5 and $\mathbf{6}$ ), which did show an interaction with ctDNA, as evidenced by the decrease in fluorescence intensity of the solutions. The Stern-Volmer constants (Ksv) for $\mathbf{5}$ and $\mathbf{6}$ were equal to $(1.6 \pm 0.2) \times 10^{3} \mathrm{mM}^{-1}$ and $(3.3 \pm 0.6) \times 10^{3} \mathrm{mM}^{-1}$, respectively. These data show that the DNA binding affinity for 6 is almost twice as effective as that of $\mathbf{5}$, indicating that not only the apical ligands but also the inner ligands may play a role in binding to DNA. The enhanced binding of the selenium cluster 6 to DNA also explains the enhanced accumulation of this compound in nucleus observed by confocal.

To confirm that the results are really due to interaction of the clusters with DNA we also undertook blank experiments in the absence of ctDNA (Figures S39) At concentrations of clusters 5 and 6 from $3.8 \times 10^{-2} \mathrm{mM}$ and above, the emission of EB (which in fact is significantly less intensive in the absence of DNA) started demonstrating some noticeable quenching (Fig. S39). This quenching with $\mathrm{K}_{\mathrm{sv}}=15 \pm 1 \mathrm{mM}^{-1}$ for both complexes is an indication of some sort of interaction of clusters with EB, which is, however, weaker than the interaction of the clusters with ctDNA.

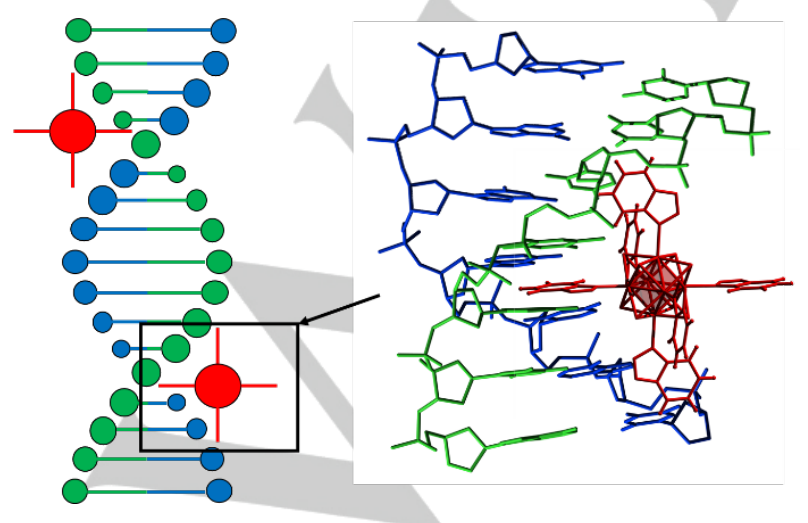

Figure 9. Schematic representation of suggested interaction of DNA with rhenium clusters.
Whilst the exact mechanism of binding to DNA is not uncovered, a plausible explanation for the affinity of the btrz clusters over 1,2,3-triazole ones could be the interaction of significantly larger aromatic system of benzotriazole with the nucleotide bases e.g. $\pi-\pi$ stacking that would enhance DNA intercalation. Indeed, this mechanism was suggested earlier in the design of benzotriazole or benzimidazole based organic molecules and metal complexes with antibacterial, antifungal and anticancer activity. ${ }^{[18]}$ To understand the role of the clusters in binding to DNA, free benzotriazole alone, was tested in the competitive binding experiments. Our data suggest that benzotriazole does indeed bind to DNA, but significantly less effectively than the clusters: for comparison $\mathrm{Ksv}=3.9 \pm 0.7 \mathrm{mM}^{-1}$ (Fig. S40) for binding of benzotriazole to DNA, i.e. it is three orders of magnitude lower than that for $\mathbf{5}$ and $\mathbf{6}$. This experiment demonstrated the significant role of the cluster core in facilitating of binding of the cluster complexes $\mathbf{5}$ and $\mathbf{6}$ to DNA. We suggest that metal cluster provides effective orientational scaffolding for benzotriazole ligands, which facilitates binding of the clusters to DNA (Fig. 9).

\section{Conclusion}

In summary, we synthesized and characterized four new watersoluble anionic rhenium cluster complexes baring 1,2,3-triazole and 1,2,4-ligands. The complexes with $\left[\left\{\operatorname{Re}_{6} \mathrm{Q}_{8}\right\}(1,2,3-\operatorname{trz})_{6}\right]^{4-}$ crystalize as a single geometric isomer, while $\left[\left\{\operatorname{Re}_{6} Q_{8}\right\}(1,2,4-\right.$ trz)6 $]^{4-}$ represents a mixture of a range of geometric isomers. The study of optical and electro-chemical properties demonstrated that the complexes with the same inner ligands are generally similar from the point of view of electronic structure to their benzotriazole analogues $\left[\left\{\operatorname{Re}_{6} \mathrm{Q}_{8}\right\}(\mathrm{btrz})_{6}\right]^{4-}$. The study of biological properties revealed that despite the negative charge of the complexes internalization of the complexes with benzotriazole into HeLa and fibroblasts was better than those with triazole ligands. Moreover, the localization of the benzotriazole complexes within the cells' nucleus region suggested that there could be binding of with DNA. This assumption was indeed supported by the DNA binding test using EB as a marker. Notably, complexes with triazoles did not demonstrate any binding to free DNA. Our study, therefore, indeed confirmed that the presence of such hydrophobic, but m-rich unit as benzene ring is a driving force for the rhenium complexes cellular internalization.

\section{Experimental Section}

\section{Materials and Methods}

$\mathrm{K}_{4}\left[\left\{\mathrm{Re}_{6} \mathrm{Q}_{8}\right\}(\mathrm{OH})_{6}\right] \cdot 8 \mathrm{H}_{2} \mathrm{O}(\mathrm{Q}=\mathrm{S}$, Se) was obtained according to the literature procedure. ${ }^{[7 \mathrm{~b}]} \mathrm{Na}_{4}\left[\left\{\mathrm{Re}_{6} \mathrm{Q}_{8}\right\}(\mathrm{OH})_{6}\right]$ was synthesized from $\left[\left\{\mathrm{Re}_{6} \mathrm{Q}_{8}\right\}\left(\mathrm{H}_{2} \mathrm{O}\right)_{4}(\mathrm{OH})_{2}\right]$ according to the procedure described recently, ${ }^{[10]}$ while compounds $\mathrm{K}_{4}\left[\left\{\mathrm{Re}_{6} \mathrm{~S}_{8}\right\}(\mathrm{btrz})_{6}\right] \cdot 3.5 \mathrm{EtOH} \cdot 4 \mathrm{H}_{2} \mathrm{O} \quad\left(\mathrm{K}_{4}-5\right)$ and $\mathrm{K}_{2.75} \mathrm{H}_{1.25}\left[\left\{\mathrm{Re}_{6} \mathrm{Se}_{8}\right\}(\mathrm{btrz})_{6}\right] \cdot 3 \mathrm{EtOH} \cdot 7 \mathrm{H}_{2} \mathrm{O}\left(\mathrm{K}_{4}-6\right)$ according to the method described in ${ }^{[4 \mathrm{~b}]}$. All other reactants and solvents were purchased from Fisher, Alfa Aesar and Sigma-Aldrich and used as received. Elemental analyses were obtained using a EuroVector EA3000 Elemental Analyser. FTIR spectra (Fig. S41-S43) were recorded on a Bruker Vertex 80 as $\mathrm{KBr}$ disks. Energy-dispersive X-ray spectroscopy (EDS) was performed on a Hitachi TM3000 TableTop SEM with Bruker QUANTAX 70 EDS equipment. Absorption spectra were recorded on a Cary 60 UV-Vis 
This is the peer reviewed version of the following article: D. I. Konovalov, A. A. Ivanov, T. S. Frolova, I. V. Eltsov, Y. M. Gayfulin, L. Plunkett, M. Bazzar, A. M. Adawi, J.-S. G. Bouillard, S. I. Baiborodin, O. I. Sinitsyna, N. V. Kuratieva, V. V. Yanshole, O. A. Efremova, M. A.

Shestopalov, Chem. Eur. J. 2020, 26, 13904., which has been published in final form at https://doi.org/10.1002/chem.202001680. This article may be used for non-commercial purposes in accordance with Wiley Terms and Conditions for self-archiving.

Spectrophotometer (Agilent). The high-resolution electrospray mass spectrometric (HR-ESI-MS) detection was performed at the Center of Collective Use «Mass spectrometric investigations» SB RAS in negative mode within $500-3000 \mathrm{~m} / \mathrm{z}$ range on an electrospray ionization quadrupole time-of-filght (ESI-q-TOF) high-resolution mass spectrometer Maxis 4G (Bruker Daltonics, Germany). The 1D and 2D NMR spectra were recorded from a DMSO- $\mathrm{d}^{6}$ solution at room temperature on a Bruker Avance III 500 FT-spectrometer with working frequencies $500.03,125.73$ and $50.67 \mathrm{MHz}$, for ${ }^{1} \mathrm{H},{ }^{13} \mathrm{C}$, and ${ }^{15} \mathrm{~N}$ nuclei, respectively. The ${ }^{1} \mathrm{H}$ and ${ }^{13} \mathrm{C}$ NMR chemical shifts are reported in ppm of the $\delta$ scale and referred to signals of the solvents $\left(2.50 \mathrm{ppm}\right.$ for residual protons for ${ }^{1} \mathrm{H}$ and $39.50 \mathrm{ppm}$ for ${ }^{13} \mathrm{C}$ NMR spectra respectively). ${ }^{15} \mathrm{~N}$ NMR spectrum was obtained as projection of 2D ${ }^{1} \mathrm{H}-{ }^{15} \mathrm{~N}$ - correlation. The ${ }^{15} \mathrm{~N}$ NMR chemical shifts are referred to external standard of formamide $\left(\delta\left({ }^{15} \mathrm{~N}\right)=112.5 \mathrm{ppm}\right)$. Assignment of the signals were carried out using 2-D (HSQC, HMBC, COSY) NMR techniques.

\section{Synthetic procedures}

\section{Syntheses of $\mathrm{K}_{4}\left[\left\{\operatorname{Re}_{6} \mathrm{~S}_{8}\right\}(1,2,3-\mathrm{trz})_{6}\right] \cdot \mathrm{EtOH} \quad\left(\mathrm{K}_{4}-1\right) \quad$ and} $\mathrm{K}_{4}\left[\left\{\mathrm{Re}_{6} \mathrm{Se}_{8}\right\}(1,2,3-\mathrm{trz})_{6}\right] \cdot \mathrm{EtOH} \cdot \mathbf{2 H}_{2} \mathrm{O}\left(\mathrm{K}_{4}-2\right)$. $\mathrm{K}_{4}\left[\left\{\mathrm{Re}_{6} \mathrm{Q}_{8}\right\}(\mathrm{OH})_{6}\right] \cdot 8 \mathrm{H}_{2} \mathrm{O}(200$ $\mathrm{mg}, 0.112 \mathrm{mmol}(\mathrm{Q}=\mathrm{S})$ or $0.092 \mathrm{mmol}(\mathrm{Q}=\mathrm{Se}))$ and $1,2,3-\operatorname{trzH}(200 \mathrm{mg}$, $2.897 \mathrm{mmol}$ ) were heated in a sealed glass tube at $200^{\circ} \mathrm{C}$ for 2 days. After that tubes were opened and the reaction mixtures were dissolved in ethanol $(30 \mathrm{~mL})$ under heating. Solutions obtained were filtered from unreacted cluster, evaporated to around $5 \mathrm{~mL}$ and precipitated by excess of ethyl acetate. The resulted powders usually contain solvate 1,2,3triazole molecules, which can be removed by few extra steps: conversion of the salt into the neutral water-insoluble $\left[\left\{\operatorname{Re}_{6} \mathrm{Q}_{8}\right\}(1,2,3 \text {-trzH })_{4}(1,2,3-\operatorname{trz})_{2}\right]$ with the help of $1 \mathrm{M} \mathrm{HCl}$, followed by the conversion of the neutral complex back into the salt by $\mathrm{KOH}$ into ethanol and finally recrystallisation from DMSO by precipitation of the neat product with ethyl acetate. As assessed by CHNS analysis the product sometimes contained 1-2 molecules of DMSO per formula unit, which could be isolated by re-precipitation from ethanol by $\mathrm{CH}_{2} \mathrm{Cl}_{2}$. The final products were dried in air.

$\mathrm{K}_{4}-1: 170 \mathrm{mg}$ (72 \%), Anal. Calcd. for $\mathrm{C}_{14} \mathrm{H}_{18} \mathrm{~K}_{4} \mathrm{~N}_{18} \mathrm{ORe}_{6} \mathrm{~S}_{8}$ : C, 8.5; $\mathrm{H}, 0.9$; $\mathrm{N}, 12.7$; S, 12.9. Found: C, 8.6; H, 0.8; N, 12.4; S, 12.8. EDS: Re:S:K atomic ratio was equal to $6: 8.1: 3.8$. ${ }^{1} \mathrm{H}$ NMR $(500 \mathrm{MHz}, \mathrm{DMSO}) \delta 7.31$ (s, $1 \mathrm{H}, 5-\mathrm{CH}), 7.81$ (s, 1H, 4-CH). ${ }^{13} \mathrm{C}$ NMR (126 MHz, DMSO) $\delta 129.39$ (5C), 139.01 (4-C). ${ }^{15} \mathrm{~N} \mathrm{NMR}\left(51 \mathrm{MHz}, \mathrm{HCONH}_{2}\right) \delta 252(3-\mathrm{N}), 350(2-\mathrm{N}), 396$

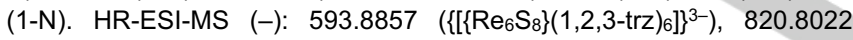
$\left(\left\{\left[\left\{\operatorname{Re}_{6} \mathrm{~S}_{8}\right\}(1,2,3-\operatorname{trz})_{4}\right]\right\}^{-}\right), \quad 856.8146\left(\left\{\left[\left\{\operatorname{Re}_{6} \mathrm{~S}_{8}\right\}(1,2,3-\operatorname{trz})_{5}\right]\right\}^{2-}\right), \quad 876.2964$ $\left.\left(\left\{\mathrm{K}_{\{} \operatorname{Re}_{6} \mathrm{~S}_{8}\right\}(1,2,3-\mathrm{trz})_{5}\right]^{2-}\right), 929.7906\left(\left\{\mathrm{~K}_{2}\left[\left\{\operatorname{Re}_{6} \mathrm{~S}_{8}\right\}(1,2,3-\operatorname{trz})_{6}\right]^{2-}\right)\right.$. The TGA analysis indicated stability up to $180^{\circ} \mathrm{C}$ with a weight loss of approximately $2.4 \%$ between 40 and $110^{\circ} \mathrm{C}$ (the theoretical weight loss of $\mathrm{EtOH}$ is $2.3 \%$ ) (Fig. S44). The single crystals of $\mathrm{K}_{4}-1 \cdot 6(1,2,3-\mathrm{trzH}) \cdot 4 \mathrm{H}_{2} \mathrm{O}$ suitable for $\mathrm{X}$ ray structural analyses were separated manually from the melts.

$\mathrm{K}_{4}-2: 180 \mathrm{mg}(80 \%)$, Anal. Calcd. for $\mathrm{C}_{14} \mathrm{H}_{22} \mathrm{~K}_{4} \mathrm{~N}_{18} \mathrm{O}_{3} \mathrm{Re}_{6} \mathrm{Se}_{8}$ : C, 7.0; $\mathrm{H}$, $0.9 ; \mathrm{N}, 10.5$. Found: $\mathrm{C}, 7.2 ; \mathrm{H}, 0.9 ; \mathrm{N}, 10.3$. EDS: Re:Se:K atomic ratio was equal to 6:8.2:3.9. ${ }^{1} \mathrm{H}$ NMR ( $500 \mathrm{MHz}$, DMSO) $\delta 7.21(\mathrm{~s}, 1 \mathrm{H}, 5-\mathrm{CH}), 7.90$ (s, $1 \mathrm{H}, 4-\mathrm{CH}) .{ }^{13} \mathrm{C}$ NMR $(126 \mathrm{MHz}, \mathrm{DMSO}) \delta 128.85$ (5-C), 141.62 (4-C).

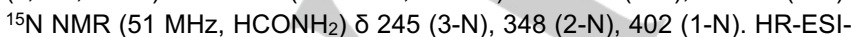
MS (-): 719.0724 (\{[\{Re6Se8\}(1,2,3-trz) 6$\left.]\}^{3-}\right), 1010.5829$ (\{[\{Re6Se8\}(1,2,3trz $\left.\left.\left.)_{4}\right]\right\}^{2-}\right), \quad 1044.5954 \quad\left(\left\{\left[\left\{\operatorname{Re}_{6} \mathrm{Se}_{8}\right\}(1,2,3-\operatorname{trz})_{5}\right]\right\}^{2-}\right), \quad 1065.0770$ $\left(\left\{\mathrm{K}\left[\left\{\mathrm{Re}_{6} \mathrm{Se}_{8}\right\}(1,2,3-\mathrm{trz})_{5}\right]^{2-}\right), \quad 1098.0897 \quad\left(\left\{\mathrm{~K}\left[\left\{\mathrm{Re}_{6} \mathrm{Se}_{8}\right\}(1,2,3-\mathrm{trz})_{6}\right]^{2-}\right)\right.\right.$, $1118.5713\left(\left\{\mathrm{~K}_{2}\left[\left\{\operatorname{Re}_{6} \mathrm{~S}_{8}\right\}(1,2,3-\mathrm{trz})_{6}\right]^{2-}\right)\right.$. The TGA analysis indicated stability up to $180^{\circ} \mathrm{C}$ with a weight loss of approximately $3.5 \%$ between 40 and $120^{\circ} \mathrm{C}$ (the theoretical weight loss of $\mathrm{EtOH}$ and $2 \mathrm{H}_{2} \mathrm{O}$ is $3.4 \%$ ) (Fig. S44). The single crystals of $\mathrm{K}_{4}-2 \cdot 6(1,2,3-$ trzH) suitable for $\mathrm{X}$-ray structural analyses were separated manually from the melts.

Syntheses of $\mathrm{K}_{4}\left[\left\{\mathrm{Re}_{6} \mathrm{~S}_{8}\right\}(1,2,4-\operatorname{trz})_{6}\right] \cdot 2 \mathrm{EtOH} \cdot 3 \mathrm{H}_{2} \mathrm{O} \quad\left(\mathrm{K}_{4}-3\right)$ and $\mathrm{K}_{4}\left[\left\{\mathrm{Re}_{6} \mathrm{Se}_{8}\right\}(1,2,4-\mathrm{trz})_{6}\right] \cdot \mathrm{EtOH} \cdot 3 \mathrm{H}_{2} \mathrm{O}\left(\mathrm{K}_{4}-4\right)$. Compounds were obtained using same procedure as for $\mathrm{K}_{4}-1$ and $\mathrm{K}_{4}-2$ from $\mathrm{K}_{4}\left[\left\{\mathrm{Re}_{6} \mathrm{Q}_{8}\right\}(\mathrm{OH})_{6}\right] \cdot 8 \mathrm{H}_{2} \mathrm{O}$ $(200 \mathrm{mg}, 0.112 \mathrm{mmol}(\mathrm{Q}=\mathrm{S})$ or $0.092 \mathrm{mmol}(\mathrm{Q}=\mathrm{Se}))$ and 1,2,4-trzH $(200$ $\mathrm{mg}, 2.897 \mathrm{mmol}$ ).
$\mathrm{K}_{4}-3: 190 \mathrm{mg}$ (81\%), Anal. Calcd. for $\mathrm{C}_{16} \mathrm{H}_{30} \mathrm{~K}_{4} \mathrm{~N}_{18} \mathrm{O}_{5} \mathrm{Re}_{6} \mathrm{~S}_{8}$ : C, 9.2; H, 1.4; $\mathrm{N}, 12.1 ; \mathrm{S}, 12.3$. Found: C, 9.1; H, 1.5; N, 12.2; S, 12.5. EDS: Re:S:K atomic ratio was equal to 6:7.9:3.9. ${ }^{1} \mathrm{H}$ NMR $(500 \mathrm{MHz}$, DMSO) $\delta 7.56-$ $7.67(\mathrm{~m}, 1 \mathrm{H}, 5-\mathrm{H}$ for the type $\mathrm{I}), 8.00-8.10(\mathrm{~m}, 1 \mathrm{H}, 3-\mathrm{H}$ for the type $\mathrm{I}), 8.10-$ $8.22\left(\mathrm{~m}, 2.46 \mathrm{H}, 3,5-\mathrm{H}\right.$ for the type II). ${ }^{13} \mathrm{C}$ NMR (126 MHz, DMSO) $\delta$ $151.50-150.60$ (3-C for the type I), $155.29-155.36$ (3,5-C for the type II), 158.44-158-64 (5-C for the type I). ${ }^{15} \mathrm{~N} \mathrm{NMR}\left(51 \mathrm{MHz}, \mathrm{HCONH}_{2}\right) \delta 219$ (4$\mathrm{N}$ for the type I), 248 (2-N for the type I), 312 (4-N for the type II), 329 (1$\mathrm{N}$ for the type I. HR-ESI-MS $(-)$ : $593.8849\left(\left\{\left[\left\{\operatorname{Re}_{6} \mathrm{~S}_{8}\right\}(1,2,4-\operatorname{trz}) 6\right]\right\}^{3-}\right)$, $820.8022\left(\left\{\left[\left\{\operatorname{Re}_{6} \mathrm{~S}_{8}\right\}(1,2,4-\operatorname{trz}) 4\right]\right\}^{2-}\right), \quad 856.8146\left(\left\{\left[\left\{\operatorname{Re}_{6} \mathrm{~S}_{8}\right\}(1,2,4-\operatorname{trz}) 5\right]\right\}^{2-}\right)$,

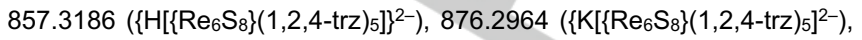
$929.7906\left(\left\{\mathrm{~K}_{2}\left[\left\{\mathrm{Re}_{6} \mathrm{~S}_{8}\right\}(1,2,4-\mathrm{trz})_{6}\right]^{2-}\right)\right.$. The TGA analysis indicated stability up to $260{ }^{\circ} \mathrm{C}$ with a weight loss of approximately $6.9 \%$ between 50 and $200{ }^{\circ} \mathrm{C}$ (the theoretical weight loss of $2 \mathrm{EtOH}$ and $3 \mathrm{H}_{2} \mathrm{O}$ is $7.0 \%$ ) (Fig. S45).

$\mathrm{K}_{4}-4$ : $175 \mathrm{mg}$ (78 \%), Anal. Calcd. for $\mathrm{C}_{14} \mathrm{H}_{24} \mathrm{~K}_{4} \mathrm{~N}_{18} \mathrm{O}_{4} \mathrm{Re}_{6} \mathrm{Se}$ : $\mathrm{C}, 6.9 ; \mathrm{H}$, 1.0; N, 10.4. Found: $\mathrm{C}, 7.1 ; \mathrm{H}, 0.8 ; \mathrm{N}, 10.2$. EDS: Re:Se:K atomic ratio was equal to 6:8.1:4.0. ${ }^{1} \mathrm{H}$ NMR (500 MHz, DMSO) $\delta 7.49-7.59(\mathrm{~m}, 1 \mathrm{H}, 5-\mathrm{H}$ for the type I), 8.00-8.20 (m, $1 \mathrm{H}, 3-\mathrm{H}$ for the type $\mathrm{I}), 8.15-8.22(\mathrm{~m}, 2.53 \mathrm{H}, 3,5-$ $\mathrm{H}$ for the type II). ${ }^{13} \mathrm{C}$ NMR (126 MHz, DMSO) $\delta 149.60-150.30$ (3-C for the type I), $157.58-158.08$ (3,5-C for the type II), 160.56-161.21 (5-C for the type I). $\left.{ }^{15} \mathrm{~N} \mathrm{NMR} \mathrm{(51} \mathrm{MHz,} \mathrm{HCONH}{ }_{2}\right) \delta 213$ (4-N for the type I), 248 (2$\mathrm{N}$ for the type I), 308 (4-N for the type II), 336 (1-N for the type I). HR-ESI-

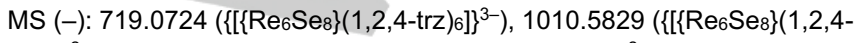
trz $\left.\left.\left.)_{4}\right]\right]^{2-}\right), \quad 1044.5954 \quad\left(\left\{\left[\left\{\operatorname{Re}_{6} \mathrm{Se}_{8}\right\}(1,2,4-\text { trz })_{5}\right]\right]^{2-}\right), \quad 1064.0770$ $\left(\left\{K\left[\left\{\operatorname{Re}_{6} \mathrm{Se}_{8}\right\}\left(1,2,4-\mathrm{trz}_{5}\right]^{2-}\right), \quad 1118.5713\left(\left\{\mathrm{~K}_{2}\left[\left\{\operatorname{Re}_{6} \mathrm{~S}_{8}\right\}\left(1,2,4-\mathrm{trz}_{6}\right]^{2-}\right) . \quad\right.\right.\right.\right.$ The TGA analysis indicated stability up to $260{ }^{\circ} \mathrm{C}$ with a weight loss of approximately $3.9 \%$ between 50 and $200{ }^{\circ} \mathrm{C}$ (the theoretical weight loss of $\mathrm{EtOH}$ and $3 \mathrm{H}_{2} \mathrm{O}$ is $4.1 \%$ ) (Fig. S45).

Syntheses of sodium salts of cluster complexes. Sodium salts $\mathrm{Na}_{4}\left[\left\{\mathrm{Re}_{6} \mathrm{~S}_{8}\right\}(1,2,3-\mathrm{trz})_{6}\right] \cdot \mathrm{EtOH} \cdot \mathrm{H}_{2} \mathrm{O} \quad\left(\mathrm{Na}_{4}-1\right), \quad \mathrm{Na}_{4}\left[\left\{\mathrm{Re}_{6} \mathrm{Se}_{8}\right\}(1,2,3-\right.$ trz) $6 \cdot 2 \mathrm{EtOH} \cdot 2 \mathrm{H}_{2} \mathrm{O}\left(\mathrm{Na}_{4}-2\right), \quad \mathrm{Na}_{4}\left[\left\{\mathrm{Re}_{6} \mathrm{~S}_{8}\right\}(1,2,4-\mathrm{trz})_{6}\right] \cdot 2 \mathrm{EtOH} \cdot \mathrm{H}_{2} \mathrm{O}\left(\mathrm{Na}_{4}-3\right)$ and $\quad \mathrm{Na}_{4}\left[\left\{\mathrm{Re}_{6} \mathrm{Se}_{8}\right\}(1,2,4-\mathrm{trz})_{6}\right] \cdot 2 \mathrm{EtOH} \cdot 2 \mathrm{H}_{2} \mathrm{O} \quad\left(\mathrm{Na}_{4}-4\right)$, $\mathrm{Na}_{4}\left[\left\{\mathrm{Re}_{6} \mathrm{~S}_{8}\right\}(\text { btrz })_{6}\right] \cdot \mathrm{EtOH} \cdot 2 \mathrm{H}_{2} \mathrm{O}\left(\mathrm{Na}_{4}-5\right), \mathrm{Na}_{4}\left[\left\{\mathrm{Re}_{6} \mathrm{Se}_{8}\right\}(\text { btrz })_{6}\right] \cdot \mathrm{EtOH} \cdot 2 \mathrm{H}_{2} \mathrm{O}$ (Na4-6) were prepared in the similar fashion the potassium salts, but using $\mathrm{Na}_{4}\left[\left\{\mathrm{Re}_{6} \mathrm{Q}_{8}\right\}(\mathrm{OH})_{6}\right]$ instead of $\mathrm{K}_{4}\left[\left\{\mathrm{Re}_{6} \mathrm{Q}_{8}\right\}(\mathrm{OH})_{6}\right]$.

$\mathrm{Na}_{4}-1$ : $162 \mathrm{mg}(71 \%)$, Anal. Calcd. for $\mathrm{C}_{14} \mathrm{H}_{20} \mathrm{~N}_{18} \mathrm{Na}_{4} \mathrm{O}_{2} \mathrm{Re}_{6} \mathrm{~S}_{8}: \mathrm{C}, 8.7 ; \mathrm{H}$, 1.0; N, 13.0; S, 13.2. Found: C, 9.0; H, 0.9; N, 13.0; S, 12.9. EDS: Re:S:Na atomic ratio was equal to $6: 8 \cdot 0: 3.8$. The TGA analysis indicated stability up to $200{ }^{\circ} \mathrm{C}$ with a weight loss of approximately $3.0 \%$ between 50 and $170{ }^{\circ} \mathrm{C}$ (the theoretical weight loss of $\mathrm{EtOH}$ and $\mathrm{H}_{2} \mathrm{O}$ is $3.3 \%$ ) (Fig. S46). The single crystals of $\mathrm{Na}_{4}-1 \cdot 4 \mathrm{EtOH} \cdot 10 \mathrm{H}_{2} \mathrm{O}$ suitable for $\mathrm{X}$-ray structural analyses were obtained by slow evaporation of ethanol solution.

Na4-2: $168 \mathrm{mg}$ (74 \%), Anal. Calcd. for $\mathrm{C}_{16} \mathrm{H}_{28} \mathrm{~N}_{18} \mathrm{Na}_{4} \mathrm{O}_{4} \mathrm{Re}_{6} \mathrm{Se}$ : $\mathrm{C}, 8.0 ; \mathrm{H}$, $1.2 ; \mathrm{N}, 10.5$. Found: $\mathrm{C}, 8.1 ; \mathrm{H}, 1.1 ; \mathrm{N}, 10.3$. EDS: Re:Se:Na atomic ratio was equal to $6: 7 \cdot 8: 3.8$. The TGA analysis indicated stability up to $200^{\circ} \mathrm{C}$ with a weight loss of approximately $5.6 \%$ between 50 and $170{ }^{\circ} \mathrm{C}$ (the theoretical weight loss of $2 \mathrm{EtOH}$ and $2 \mathrm{H}_{2} \mathrm{O}$ is $5.4 \%$ ) (Fig. S46).

Na4-3: 185 mg (80 \%), Anal. Calcd. for $\mathrm{C}_{16} \mathrm{H}_{26} \mathrm{~N}_{18} \mathrm{Na}_{4} \mathrm{O}_{3} \mathrm{Re}_{6} \mathrm{~S}_{8}$ : C, 9.7; $\mathrm{H}$, 1.3; N, 12.7; S, 12.9. Found: C, 9.6; H, 1.2; N, 12.5; S, 12.7. EDS: Re:S:Na atomic ratio was equal to $6: 8.0: 4.2$. The TGA analysis indicated stability up to $210{ }^{\circ} \mathrm{C}$ with a weight loss of approximately $5.4 \%$ between 50 and $160^{\circ} \mathrm{C}$ (the theoretical weight loss of $2 \mathrm{EtOH}$ and $\mathrm{H}_{2} \mathrm{O}$ is $5.5 \%$ ) (Fig. S47).

Na4-4: 171 mg (75 \%), Anal. Calcd. for $\mathrm{C}_{16} \mathrm{H}_{28} \mathrm{~N}_{18} \mathrm{Na}_{4} \mathrm{O}_{4} \mathrm{Re}_{6} \mathrm{Se}_{8}$ : C, 8.0; $\mathrm{H}$, 1.2; N, 10.5. Found: $\mathrm{C}, 8.1 ; \mathrm{H}, 1.0 ; \mathrm{N}, 10.2$. EDS: Re:Se:Na atomic ratio was equal to $6: 7.8: 3.9$. The TGA analysis indicated stability up to $210^{\circ} \mathrm{C}$ with a weight loss of approximately $5.4 \%$ between 50 and $160{ }^{\circ} \mathrm{C}$ (the theoretical weight loss of $2 \mathrm{EtOH}$ and $2 \mathrm{H}_{2} \mathrm{O}$ is $5.4 \%$ ) (Fig. S47).

$\mathrm{Na}_{4}-5: 224 \mathrm{mg}$ (85 \%), Anal. Calcd. for $\mathrm{C}_{38} \mathrm{H}_{34} \mathrm{~N}_{18} \mathrm{Na}_{4} \mathrm{O}_{3} \mathrm{Re}_{6} \mathrm{~S}$ : $\mathrm{C}, 20.2 ; \mathrm{H}$, $1.5 ; \mathrm{N}, 11.1$; S, 11.3. Found: C, 20.1; H, 1.6; N, 11.2; S, 11.6. EDS: $\mathrm{Re}: \mathrm{S}: \mathrm{Na}$ atomic ratio was equal to $6: 8 \cdot 1: 4.1 .{ }^{1} \mathrm{H}$ NMR $(500 \mathrm{MHz}$, DMSO) $\delta 7.04(\mathrm{~m}, 2 \mathrm{H}, 5,6-\mathrm{CH}), 7.73(\mathrm{~m}, 1 \mathrm{H}, 4-\mathrm{CH}), 8.09(\mathrm{~m}, 1 \mathrm{H}, 7-\mathrm{CH}) .{ }^{13} \mathrm{C}$ NMR 
This is the peer reviewed version of the following article: D. I. Konovalov, A. A. Ivanov, T. S. Frolova, I. V. Eltsov, Y. M. Gayfulin, L. Plunkett, M. Bazzar, A. M. Adawi, J.-S. G. Bouillard, S. I. Baiborodin, O. I. Sinitsyna, N. V. Kuratieva, V. V. Yanshole, O. A. Efremova, M. A. Shestopalov, Chem. Eur. J. 2020, 26, 13904., which has been published in final form at https://doi.org/10.1002/chem.202001680. This article may be used for non-commercial purposes in accordance with Wiley Terms and Conditions for self-archiving.

(126 MHz, DMSO) $\delta 116.56$ (4-C), 118.14 (7-C), 120.45 (5-C), 121.09 (6C), 145.37 ( $\left.3^{\prime}-\mathrm{C}\right), 146.80$ (7'-C). The TGA analysis indicated stability up to $400{ }^{\circ} \mathrm{C}$ with a weight loss of approximately $3.9 \%$ between 50 and $160{ }^{\circ} \mathrm{C}$ (the theoretical weight loss of $\mathrm{EtOH}$ and $2 \mathrm{H}_{2} \mathrm{O}$ is $3.7 \%$ ) (Fig. S48).

$\mathrm{Na}_{4}$-6: $212 \mathrm{mg}(84 \%)$, Anal. Calcd. for $\mathrm{C}_{38} \mathrm{H}_{34} \mathrm{~N}_{18} \mathrm{Na}_{4} \mathrm{O}_{3} \mathrm{Re}_{6} \mathrm{Se}_{8}$ : C, 17.3; $\mathrm{H}, 1.3 ; \mathrm{N}, 9.5$. Found: $\mathrm{C}, 17.1 ; \mathrm{H}, 1.4 ; \mathrm{N}, 9.2$. EDS: Re:Se:Na atomic ratio was equal to 6:7.8:4.0. ${ }^{1} \mathrm{H} \mathrm{NMR}(500 \mathrm{MHz}, \mathrm{DMSO}) \delta 7.01(\mathrm{~m}, 2 \mathrm{H}, 5,6-\mathrm{CH})$, $7.69(\mathrm{~m}, 1 \mathrm{H}, 4-\mathrm{CH}), 8.08(\mathrm{~m}, 1 \mathrm{H}, 7-\mathrm{CH}) .{ }^{13} \mathrm{C} N M R(126 \mathrm{MHz}, \mathrm{DMSO}) \delta$ 116.48 (4-C), 118.71 (7-C), 120.17 (5-C), 120.22 (6-C), 145.41 (3'-C), $146.89\left(7^{\prime}-\mathrm{C}\right)$. The TGA analysis indicated stability up to $400{ }^{\circ} \mathrm{C}$ with a weight loss of approximately $3.9 \%$ between 50 and $160{ }^{\circ} \mathrm{C}$ (the theoretical weight loss of $\mathrm{EtOH}$ and $2 \mathrm{H}_{2} \mathrm{O}$ is $3.8 \%$ ) (Fig. S48).

\section{Crystallography}

Single-crystal $\mathrm{X}$-ray diffraction data for $\mathrm{K}_{4}-1 \cdot 6(1,2,3-\operatorname{trz} \mathrm{H}) \cdot 4 \mathrm{H}_{2} \mathrm{O}, \mathrm{K}_{4}$ 2.6(1,2,3-trzH) and $\mathrm{Na}_{4}-1 \cdot 4 \mathrm{EtOH} \cdot 10 \mathrm{H}_{2} \mathrm{O}$ were collected at $150 \mathrm{~K}$ (for $\mathrm{K}_{4-}$ 1.6(1,2,3-trzH) $\cdot 4 \mathrm{H}_{2} \mathrm{O}$ and $\mathrm{Na}_{4}-1 \cdot 4 \mathrm{EtOH} \cdot 10 \mathrm{H}_{2} \mathrm{O}$ ) or $298 \mathrm{~K}$ (for $\mathrm{K}_{4}-2 \cdot 6(1,2,3-$ trzH)) on a Bruker Nonius X8 Apex 4K CCD diffractometer fitted with graphite monochromatized MoKa radiation $(\lambda=0.71073 \AA)$. Absorption corrections were made empirically using the SADABS program. ${ }^{[19]}$ The structures were solved by the direct method and further refined by the fullmatrix least-squares method using the SHELXTL program package. ${ }^{[19]}$ All non-hydrogen atoms were refined anisotropically. Table S2 summarizes crystallographic data, while CCDC 1994828-1994830 contain the supplementary crystallographic data for this paper. These data can be obtained free of charge from the Cambridge Crystallographic Data Centre via www.ccdc.cam.ac.uk/data_request/cif.

Photoluminescence measurements

Fluoromax-4 spectrofluorometer equipped with $150 \mathrm{~W}$ ozonefree Xe arclamp, R928P photomultiplier tube, integrating sphere Quanta- $\varphi$ and double grating excitation and emission monochromators was used for luminescence characterization such as absolute quantum yield, luminescence life-times and emission profiles. Emission spectra were corrected for source intensity (lamp and grating) and emission spectral response (detector and grating) by standard correction curves. Powdered samples of the complexes $\mathrm{Na}_{4}-\mathbf{1}, \mathrm{Na}_{4}-\mathbf{2}, \mathrm{Na}_{4}-\mathbf{3}$ and $\mathrm{Na}_{4}-\mathbf{4}$ were placed in non-fluorescent quartz cuvettes. Emission spectra in solution were measured in either $\mathrm{H}_{2} \mathrm{O}$ or $\mathrm{D}_{2} \mathrm{O}$ in quartz cuvettes. The absorbance of solutions was set at $<0.1$ at $355 \mathrm{~nm}$. The solutions were deaerated by purging the cuvettes with nitrogen gas for $30 \mathrm{~min}$ and sealed. Corrected emission spectra were recorded at $355 \mathrm{~nm}$ excitation.

\section{Cyclic Voltammetry}

Cyclic voltammetry was carried out with Elins P-20X8 voltammetry analyzer using three-electrode scheme with Pt working, GC auxiliary and $\mathrm{Ag} / \mathrm{AgCl} / 3.5 \mathrm{M} \mathrm{KCl}$ reference electrodes. Investigations were carried out for $5 \cdot 10^{-4} \mathrm{M}$ solutions of corresponding cluster compounds in $0.1 \mathrm{M} \mathrm{Bu}_{4} \mathrm{NClO}_{4}$ in DMSO under $\mathrm{Ar}$ atmosphere. The registered value of $\mathrm{E}_{1 / 2}$ for $\mathrm{Fc}^{0 /+}$ couple was $0.405 \mathrm{~V}$ in the same conditions.

\section{Cell culture}

Cervical cancer cells HeLa (HeLa, CCL-2) and immortalized human fibroblasts (CRL-4025) was purchased from the American Type Culture Collection (USA) and cultured in DMEM supplemented with $10 \%$ fetal bovine serum, under a humidified atmosphere $\left(5 \% \mathrm{CO}_{2}\right.$ plus $95 \%$ air $)$ at $37^{\circ} \mathrm{C}$.

\section{MTT assay}

MTT assay was performed according to standard procedures. ${ }^{[20]}$ The cell cultures were grown on DMED containing $10 \%$ bovine serum. To each well of a 96-well plate we added $100 \mu \mathrm{L}$ of the cell suspension (density $10^{6}$ cells $/ \mathrm{ml}$ ); the plate was placed in an incubator containing $5 \% \mathrm{CO}_{2}$ at a temperature of $37^{\circ} \mathrm{C}$. After $24 \mathrm{~h}$ the test compounds were added in the required concentration. The plate was then returned to the incubator for a further 72 hours. Then, $10 \mu \mathrm{L}$ of MTT ( $5 \mathrm{mg}$ of 3-(4,5-dimethylthiazol-2-yl)2,5-diphenyltetrazolium bromide (MTT) per $1 \mathrm{ml}$ of PBS) was added to each well. 3 hours later the supernatant fluid was removed from the wells, and the precipitate was dissolved in $100 \mu \mathrm{L}$ of isopropanol. The amount of precipitate was determined on a Multiskan RC plate spectrophotometer, using the inbuilt Genesis software (LabSystems). Percent inhibition was calculated by the formula:

Inhibition $(\%)=100-[(\mathrm{T} / \mathrm{M}) \times 100]$

$\mathrm{T}$ is the optical density of the precipitate with the test compound, $\mathrm{M}$ is the optical density of the untreated cells (negative control). The experiment was repeated independently three times, with 3 replications in each. Average values were reported for all repeated experiments \pm SEM

\section{Flow cytometry}

Flow cytofluorimetry was performed using an AttuneNxT instrument (ThermoFisher Scientific). For this analysis, cells were seeded in the wells of a 6 -well plate $\left(5 \times 10^{4}\right.$ cells per well $)$ and incubated for 24 hours to attach. Then the test compounds were added in the required concentration. Cells were incubated for 24 hours, after this, cells from the wells were removed using trypsin and washed twice with $1 \mathrm{ml} \mathrm{PBS}$. After the second wash, the cells were suspended in $1 \mathrm{ml}$ of PBS and then analyzed using a cytofluorimeter. The final result is presented in the form of the relative emission units (REU \pm SEM) in the analysis of at least 30,000 cells.

\section{Confocal microscopy}

The samples for confocal microscopy were prepared as follows: a cover slip was placed into the bottom of each well of a 12 -well plate, $1 \mathrm{ml}$ of cell culture medium and $100 \mu \mathrm{L}$ of cell suspension (density $10^{6}$ cell per ml) were then added to each well. The cells were incubated for 24 hours, and then washed with PBS. After that, to each well was added a sample of one of the clusters under test, dissolved in cell culture medium at the desired concentration. After $24 \mathrm{~h}$ of incubation the cover slips were removed from the plate, carefully washed with PBS and put into paraformaldehyde overnight. Subsequently, each coverslip was placed on a slide with antifade containing DAPI. The sample was dried with filter paper and the edges of the coverslips were sealed to the slides with lacquer. Microscopic examination was carried out with the help of an LSM 510 META (Carl Zeiss) confocal scanning microscope at the Center for Microscopic Analysis of Biological Objects of the Institute of Cytology and Genetics SB RAS. Standard filters were used for detection of clusters $(405 \mathrm{~nm}$ for excitation and $650-700 \mathrm{~nm}$ for emission). The results were processed using Zen (Carl Zeiss) software.

\section{Electrophoretic mobility shift assay}

Plasmid pUC19 was provided by SybEnzyme (Novosibirsk, Russia). Clusters at concentration of $0.04 \mu \mathrm{M}$ were incubated with plasmid DNA pUC19 $(0.5 \mu \mathrm{g})$ at $37^{\circ}$ for $24 \mathrm{~h}$ followed by electrophoresis $(4 \mathrm{~h}$ at $100 \mathrm{~V}$ in $1.2 \%$ agarose TAE gel). Then the gel was staining with ethidium bromide and results were detected in UV.

\section{Fluorescence titration}

DNA sodium salt from calf thymus (ctDNA) was purchased from SigmaAldrich. Cluster compounds Na4-1, Na4-2, $\mathrm{K}_{4}-\mathbf{5}$ and $\mathrm{K}_{4}-\mathbf{6}$ were investigated for their ability to bind to DNA via displacement of EB from EB-ctDNA complexes. The tested solutions were prepared by mixing $2 \mathrm{~mL}$ of ctDNA (100 $\mathrm{g} \mathrm{mL}^{-1}$ in TRIS buffer solution) and $2 \mu \mathrm{L}$ of EB solution (10 $\mathrm{mg} \mathrm{mL}^{-1}$ ) to which separate aliquots of $0,20,30,40,50$ or $100 \mu \mathrm{L}$ of the cluster 
This is the peer reviewed version of the following article: D. I. Konovalov, A. A. Ivanov, T. S. Frolova, I. V. Eltsov, Y. M. Gayfulin, L. Plunkett, M. Bazzar, A. M. Adawi, J.-S. G. Bouillard, S. I. Baiborodin, O. I. Sinitsyna, N. V. Kuratieva, V. V. Yanshole, O. A. Efremova, M. A. Shestopalov, Chem. Eur. J. 2020, 26, 13904., which has been published in final form at https://doi.org/10.1002/chem.202001680. This article may be used for non-commercial purposes in accordance with Wiley Terms and Conditions for self-archiving.

stock solutions ( $0.38 \mathrm{mM}$ in DMSO) were added and made up to $10 \mathrm{~mL}$ using Tris-Buffer solution. The luminescence of the solutions was measured on a HORBIA Scientific fluormax-4 spectrofluorometer with a HORBIA DM303 current acquisition module between 520-720 nm using a $405 \mathrm{~nm}$ excitation source at room temperature. To study effect of benzotriazole on EB-ctDNA, aliquots of a stock solution of benzotriazole (2.28 $\mathrm{mM}$ in TRIS buffer solution) equal to $0,20,40,100 \mu \mathrm{L}$ were used. To study influence of clusters on EB luminescence, the same concentrations of EB were studied, but with the addition of other aliquots of cluster stock solution $(100,200,500$, and $1250 \mu \mathrm{L})$. Luminescence was detected at $550-750 \mathrm{~nm}$ upon excitation with a wavelength of $520 \mathrm{~nm}$ in order to exclude the effect of luminescence of the cluster complexes.

\section{Acknowledgements}

This work was supported by Russian Science Foundation [grant no. 19-73-20109]. Authors acknowledge Ministry of science and higher education of RF. The authors thank the Center for Collective Use of Microscopic Analysis of Biological Objects (Institute of Cytology and Genetics, Siberian Branch of Russian Academy of Science, Novosibirsk, Russia) for providing the equipment.

Keywords: rhenium cluster $\cdot$ triazoles $•$ luminescence $•$ cytotoxicity $\cdot$ DNA binding

[1] a) N. Kitamura, Y. Ueda, S. Ishizaka, K. Yamada, M. Aniya, Y. Sasaki, Inorg. Chem. 2005, 44, 6308-6313; b) T. Yoshimura, S. Ishizaka, Y. Sasaki, H.-B. Kim, N. Kitamura, N. G. Naumov, M. N. Sokolov, V. E. Fedorov, Chem. Lett. 1999, 28, 1121-1122.

[2] A. A. Krasilnikova, A. O. Solovieva, A. A. Ivanov, K. E. Trifonova, T. N. Pozmogova, A. R. Tsygankova, A. I. Smolentsev, E. I. Kretov, D. S. Sergeevichev, M. A. Shestopalov, Y. V. Mironov, A. M. Shestopalov, A. F. Poveshchenko, L. V. Shestopalova, Nanomedicine: NBM 2017, 13, 755-763.

[3] a) L. Gao, M. A. Peay, T. G. Gray, Chem. Mater. 2010, 22, 6240-6245; b) A. O. Solovieva, K. Kirakci, A. A. Ivanov, P. Kubát, T. N. Pozmogova, S. M. Miroshnichenko, E. V. Vorontsova, A. V. Chechushkov, K. E. Trifonova, M. S. Fufaeva, E. I. Kretov, Y. V. Mironov, A. F. Poveshchenko, K. Lang, M. A. Shestopalov, Inorg. Chem. 2017, 56, 13491-13499.

[4] a) J. G. Elistratova, K. A. Brylev, A. O. Solovieva, T. N. Pozmogova, A. R. Mustafina, L. V. Shestopalova, M. A. Shestopalov, V. V. Syakayev, A. A. Karasik, O. G. Sinyashin, J. Photochem. Photobiol. A 2017, 340, 4652 ; b) M. A. Shestopalov, K. E. Zubareva, O. P. Khripko, Y. I. Khripko, A. O. Solovieva, N. V. Kuratieva, Y. V. Mironov, N. Kitamura, V. E. Fedorov, K. A. Brylev, Inorg. Chem. 2014, 53, 9006-9013.

[5] O. A. Efremova, K. A. Brylev, O. Kozlova, M. S. White, M. A. Shestopalov, N. Kitamura, Y. V. Mironov, S. Bauer, A. J. Sutherland, J. Mater. Chem. C 2014, 2, 8630-8638

[6] a) F. Camerel, F. Kinloch, O. Jeannin, M. Robin, S. K. Nayak, E. Jacques, K. A. Brylev, N. G. Naumov, Y. Molard, Dalton Trans. 2018, 47, 1088410896; b) Y. Molard, A. Ledneva, M. Amela-Cortes, V. Cîrcu, N. G. Naumov, C. Mériadec, F. Artzner, S. Cordier, Chem. Mater. 2011, 23, 5122-5130.

[7] a) N. G. Naumov, A. V. Virovets, Y. V. Mironov, S. B. Artemkina, V. E. Fedorov, Ukr. Chem. J. 1999, 65, 21-27; b) S. S. Yarovoi, Y. V. Mironov, D. Y. Naumov, Y. V. Gatilov, S. G. Kozlova, S.-J. Kim, V. E. Fedorov, Eur. J. Inorg. Chem. 2005, 2005, 3945-3949; c) H. Imoto, N. G. Naumov, A. V. Virovets, T. Saito, V. E. Fedorov, J. Struct. Chem. 1998, 39, 720 727 ; d) N. G. Naumov, A. V. Virovets, N. V. Podberezskaya, V. E. Fedorov, J. Struct. Chem. 1997, 38, 857-862.

[8] H. Lusic, M. W. Grinstaff, Chem. Rev. 2013, 113, 1641-1666.

[9] a) A. A. Ivanov, V. K. Khlestkin, K. A. Brylev, I. V. Eltsov, A. I. Smolentsev, Y. V. Mironov, M. A. Shestopalov, J. Coord. Chem. 2016, 69, 841-850; b) A. A. Ivanov, D. I. Konovalov, T. N. Pozmogova, A. O. Solovieva, A.
R. Melnikov, K. A. Brylev, N. V. Kuratieva, V. V. Yanshole, K. Kirakci, K. Lang, S. N. Cheltygmasheva, N. Kitamura, L. V. Shestopalova, Y. V. Mironov, M. A. Shestopalov, Inorg. Chem. Front. 2019, 6, 882-892; c) A. A. Krasilnikova, M. A. Shestopalov, K. A. Brylev, I. A. Kirilova, O. P. Khripko, K. E. Zubareva, Y. I. Khripko, V. T. Podorognaya, L. V. Shestopalova, V. E. Fedorov, Y. V. Mironov, J. Inorg. Biochem. 2015, 144, 13-17; d) A. A. Krasilnikova, A. O. Solovieva, A. A. Ivanov, K. A. Brylev, T. N. Pozmogova, M. A. Gulyaeva, O. G. Kurskaya, A. Y. Alekseev, A. M. Shestopalov, L. V. Shestopalova, A. F. Poveshchenko, O. A. Efremova, Y. V. Mironov, M. A. Shestopalov, Toxicol Res. 2017, 6, 554-560.

[10] A. A. Krasilnikova, A. O. Solovieva, K. E. Trifonova, K. A. Brylev, A. A. Ivanov, S.-J. Kim, M. A. Shestopalov, M. S. Fufaeva, A. M. Shestopalov, Y. V. Mironov, A. F. Poveshchenko, L. V. Shestopalova, Contrast Media Mol. Imaging 2016, 11, 459-466.

[11] a) D. I. Konovalov, A. A. Ivanov, Y. A. Vorotnikov, K. A. Brylev, I. V. Eltsov, N. V. Kuratieva, N. Kitamura, Y. V. Mironov, M. A. Shestopalov, Inorg. Chim. Acta 2019, 498, 119128; b) D. I. Konovalov, A. A. Ivanov, Y. A. Vorotnikov, A. I. Smolentsev, I. V. Eltsov, O. A. Efremova, N. Kitamura, Y. V. Mironov, M. A. Shestopalov, Polyhedron 2019, 165, 79-85.

[12] R. M. Claramunt, C. López, D. Sanz, I. Alkorta, J. Elguero, Heterocycles 2001, 55, 2109-2121.

[13] I. Łakomska, K. Stefańczak, M. Fandzloch, J. Sitkowski, B. Filip-Psurska, A. Wojtczak, Polyhedron 2016, 108, 33-39.

[14] a) Z.-N. Chen, T. Yoshimura, M. Abe, K. Tsuge, Y. Sasaki, S. Ishizaka, H.-B. Kim, N. Kitamura, Chem. Eur. J. 2001, 7, 4447-4455; b) T. Yoshimura, A. Matsuda, Y. Ito, S. Ishizaka, S. Shinoda, H. Tsukube, N. Kitamura, A. Shinohara, Inorg. Chem. 2010, 49, 3473-3481; c) T. Yoshimura, K. Umakoshi, Y. Sasaki, S. Ishizaka, H.-B. Kim, N. Kitamura, Inorg. Chem. 2000, 39, 1765-1772.

[15] A. A. Ivanov, C. Falaise, P. A. Abramov, M. A. Shestopalov, K. Kirakci, K. Lang, M. A. Moussawi, M. N. Sokolov, N. G. Naumov, S. Floquet, D. Landy, M. Haouas, K. A. Brylev, Y. V. Mironov, Y. Molard, S. Cordier, E. Cadot, Chem. Eur. J. 2018, 24, 13467-13478.

[16] a) S. Fujii, T. Horiguchi, S. Akagi, N. Kitamura, Inorg. Chem. 2016, 55, 10259-10266; b) T. Yoshimura, K. Umakoshi, Y. Sasaki, A. G. Sykes, Inorg. Chem. 1999, 38, 5557-5564.

[17] a) S. Kathiresan, S. Mugesh, J. Annaraj, M. Murugan, New J. Chem. 2017, 41, 1267-1283; b) W. D. Wilson, L. Ratmeyer, M. Zhao, L. Strekowski, D. Boykin, Biochemistry 1993, 32, 4098-4104.

[18] a) Y. Ren, L. Zhang, C.-H. Zhou, R.-X. Geng, Med. chem. 2014, 4, 640662; b) N. Ling, X. Wang, D. Zeng, Y.-W. Zhang, X. Fang, H.-X. Yang, J. Mol. Struct. 2020, 1206, 127641; c) G. Onar, C. Gürses, M. O. Karataş, S. Balcıoğlu, N. Akbay, N. Özdemir, B. Ateş, B. Alıcı, J. Organomet. Chem. 2019, 886, 48-56; d) G. Onar, M. O. Karataş, S. Balcıoğlu, T. T. Tok, C. Gürses, I. Kılıç-Cıkla, N. Özdemir, B. Ateş, B. Alıcı, Polyhedron 2018, 153, 31-40; e) H. Liu, L. Gopala, S. R. Avula, P. Jeyakkumar, X. Peng, C. Zhou, R. Geng, Chin. J. Chem. 2017, 35, 483-496.

[19] Bruker, APEX2 (Version 1.08), SAINT (Version 07.03), SADABS (Version 02.11), SHELXTL (Version 06.12), Bruker AXS Inc., Madison, WI, USA 2004.

[20] T. Mosmann, J. Immunol. Methods 1983, 65, 55-63. 
This is the peer reviewed version of the following article: D. I. Konovalov, A. A. Ivanov, T. S. Frolova, I. V. Eltsov, Y. M. Gayfulin, L. Plunkett, M. Bazzar, A. M. Adawi, J.-S. G. Bouillard, S. I. Baiborodin, O. I. Sinitsyna, N. V. Kuratieva, V. V. Yanshole, O. A. Efremova, M. A. Shestopalov, Chem. Eur. J. 2020, 26, 13904., which has been published in final form at https://doi.org/10.1002/chem.202001680. This article may be used for non-commercial purposes in accordance with Wiley Terms and Conditions for self-archiving.

\section{Table of Contents}

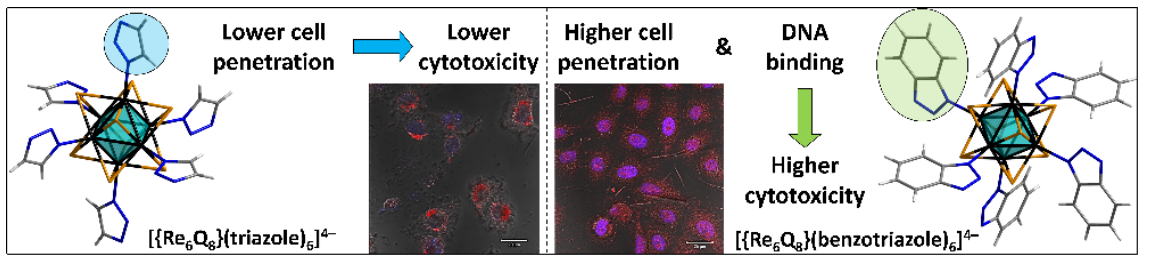

The structure of terminal triazole ligands alter the biological properties of rhenium cluster complexes, in particular their cellular internalization and toxicity profiles. Specifically, unlike clusters with 1,2,3- or 1,2,4-triazole those with benzotriazole ligands demonstrated specific cellular internalization and binding to DNA due to the $\pi$-rich benzene unit. 